\title{
Critical Race Theory and Classical- Liberal Civil Rights Scholarship: A Distinction Without a Difference?
}

\author{
Roy L. Brooks $\dagger$ \\ Mary Jo Newborn
}

We need to admit up front to our collective disadvantage in making multiculturalism a focus of this book. We are three bland middle class white men whose academic careers have focused on mainstream doctrine and the application of positive political theory to public law issues. Though one of us (Farber) is a Jew and one of us (Eskridge) is a gay man, we have not experienced exclusion in the same ways as women, lesbians, Asians, African Americans, Hispanics, and Native Americans. Partly for this reason, in our treatment of discrimination-related issues, we have relied less on our own textual exposition of different points of view (as we do in most of the book), and more on excerpting the views of scholars whose work reflects other perspectives. ${ }^{1}$

\section{INTRODUCTION}

When a standard law school casebook adopts a new legal paradigm, it is usually a sure sign that the paradigm has become an accepted part of mainstream legal culture or the canon of legal knowledge. Not everyone would agree, however, that all aspects of the newest legal paradigm, mul-

Copyright $\odot 1994$ California Law Review, Inc.

$\dagger$ Professor of Law, University of San Diego School of Law. B.A. 1972, University of Connecticut; J.D. 1975, Yale University.

$¥$ Associate Professor of Law, University of San Diego School of Law. B.A. 1984, Smith College; J.D. 1987, University of Michigan.

The authors wish to thank Philip P. Frickey and Beverly 1. Moran for helpful comments on an earlier draft of this Article.

1. Daniel A. Farber et al., Cases and Materials on Constitumonal law: Themes for tHe Constitumon's ThIRD Century iii n.4 (1993). American society “ 'is undergoing a transition from a predominantly white population rooted in Westem culture to a society composed of diverse racial and ethnic minorities.' " David Gates, White Male Paranoia, NEwSweEK, Mar. 29, 1993, at 48, 50 (quoting University of Louisville population researcher William O'Hare). Thus, "[i]n the next century, 'minorities' may no longer be in the minority -and half the population, needless to say, will still be women. More women than men are now enrolled in colleges, and by the year 2000, two out of every three new workers will be women or minorities." Id. at 50-51. 
ticultural legal scholarship (hereinafter "MLS"), deserve to be included in mainstream legal discourse. ${ }^{2}$

In this Article, we shall examine a controversial form of MLS, Critical Race Theory (hereinafter "CRT"), and will attempt to determine whether its insights and recommendations are so novel that its absence from the contemporary canon of legal knowledge would make a difference in our understanding of civil rights law (the "difference question"). ${ }^{3}$ We shall make this

2. For a general discussion of multiculturalism and the formation of canons, see, e.g., HeNRY L. Gates, JR., Loose Canons: Notes on the Culture Wars (1992). While it is always risky to attempt to define an evolving form of legal scholarship, we shall attempt to define MLS, keeping the following considerations in mind. First, some scholars are more concerned than others about the issue of doctrinal faimess to "outsider" groups (i.e., racial minorities, women, disabled Americans, homosexuals, etc.). Second, even among those who are sensitive to the outsider perspective, some scholars (i.e., MLS authors) advance that perspective more forcefully and persistently than others (e.g., classical-liberal "reformist" scholars). In other words, much, see, e.g., infra Parts III, IV.A., but not all, see, e.g., infra Part IV.B., of MLS speaks with a richer outsider voice than other scholarship within its general category. In fact, the question of doctrinal fairness to outsider groups is more than a matter of concern for MLS; it is the issue.

In light of these considerations, we propose the following as a working, or tentative, definition of MLS: scholarship that operates from the conviction that law and legal institutions are not neutral but instead vindicate a white, straight, able-bodied male perspective. Scholars who write from this perspective believe that the legitimacy of law in a multicultural society is contingent upon its willingness to incorporate outsider points of view. In short, whereas issues concerning doctrinal faimess to outsider groups are rarely raised in "mainstream" legal scholarship, other than in civil rights scholarship, such issues are central to MLS, including MLS' discussion of non-civil rights mattcrs. As a result, as MLS expands beyond civil rights analysis and into contracts, tax, and other such areas, the entire notion of mainstream legal scholarship may change. The question of doctrinal fairness to outsider groups may become a central concern, although perhaps not the central concern as it is for MLS, in mainstream discussions of non-civil rights topics. See Roy L. Brooks, Critical Feminist Theory: Toward an Understanding of Feminist Procedure, KAN. L. REv. (forthcoming Winter 1995) (suggesting that traditional procedural values may trump feminist values in the application of the doctrine of personal jurisdiction).

3. In the words of one of CRT's most prolific and imaginative scholars, Professor Richard Delgado, CRT is legal scholarship characterized by:

(1) an insistence on "naming our own reality"; (2) the belief that knowlcdge and ideas arc powerful; (3) a readiness to question basic premises of moderate/incremental civil rights law; (4) the borrowing of insights from social science on race and racism; (5) critical examination of the myths and stories powerful groups use to justify racial subordination; (6) a more contexualized treatment of doctrine; (7) criticism of liberal legalisms; and (8) an intcrest in structural determinism-the ways in which legal tools and thought-structures can impede law reform.

Richard Delgado, When a Story Is Just a Story: Does Voice Really Matter?, 76 VA. L. REv. 95,95 n.l (1990) [hereinafter Delgado, When a Story Is Just a Story].

Other writings on CRT include: Derrick A. BeLL, JR., RACE, RACISM and AMERICAN LAw (3d ed. 1992) [hereinafter Bell, Race, Racism and American law]; Derrick Bell, ANd We Are Not Saved: The Elusive Quest for Raciaz Justice (1987) [hereinafter Bell, And We ARe Not Saved; Robin D. Bames, Race Consciousness: The Thematic Content of Racial Distinctiveness in Critical Race Scholarship, 103 HARv. L. REv. 1864 (1990); Scott Brewer, Introduction: Choosing Sides in the Racial Critiques Debate, 103 HaRv. L. REv. 1844 (1990); Anthony E. Cook, Beyond Critical Legal Studies: The Reconstructive Theology of Dr. Martin Luther King, Jr., 103 HARV L. Rev. 985 (1990); Kimberle Crenshaw, Demarginalizing the Intersection of Race and Sex: A Black Feminist Critique of Antidiscrimination Doctrine, Feminist Theory and Antiracist Politics, 1989 U. CHI. LEOAL F. I39 [hereinafter Crenshaw, Demarginalizing the Intersection of Race and Sex]; Kimberle W. Crenshaw, Race, Reform, and Retrenchment: Transformation and Legitimation in Antidiscrimination Law, 101 HARv. L. REv. 1331 (1988); Jerome M. Culp, Jr., Autobiography and Legal Scholarship and Teaching: 
determination by comparing CRT's treatment of civil rights law with the accounts given by two types of "classical-liberals": "traditionalists" and "reformists." Briefly, traditionalists beheve that formal equal opportunity (hereinafter "FEO"), our nation's fundamental civil rights policy since Brown v. Board of Education, ${ }^{5}$ is basically sound both conceptually and as it has been implemented. ${ }^{6}$ Reformists, on the other hand, agree that FEO is conceptually sound but believe the policy is operationally flawed as applied by traditionalists. ${ }^{7}$ By exploring both "macrotheoretical" (i.e., fundamental, philosophical) and "microtheoretical" (i.e., issue-specific) comparisons with these classical-liberal civil rights perspectives, we will conclude that CRT is indeed a valuable new voice in modern civil rights discourse.

At least one prominent legal scholar, Judge Richard Posner, has argued that CRT, unlike another form of MLS, Critical Femimist Theory, adds very

Finding the Me in the Legal Academy, 77 VA. L. Rev. 539 (1991); Jerome M. Culp, Jr., Posner on Duncan Kennedy and Racial Difference: White Authority in the Legal Academy, 41 Duke L.J. 1095 (1992) [hereinafter Culp, Posner on Duncan Kennedy and Racial Difference]; Richard Delgado, Brewer's Plea: Critical Thoughts on Common Cause, 44 VAND. L. Rev. 1 (1991); Richard Delgado, The Imperial Scholar: Reflections on a Review of Civil Rights Literature, 132 U. PA. L. Rev. 561 (1984) [hereinafter Delgado, The Imperial Scholar]; Richard Delgado, The Imperial Scholar Revisited: How to Marginalize Outsider Writing, Ten Years Later, 140 U. PA. L. Rev. 1349 (1992); Alex M. Johnson, Jr., The New Voice of Color, 100 YALE L.J. 2007 (1991); Alex M. Johnson, Jr., Racial Critiques of Legal Academia: A Reply in Favor of Context, 43 Stan. L. Rev. 137 (1990); Randall L. Kennedy, Racial Critiques of Legal Academia, 102 HaRv. L. REv. 1745 (1989); Charles R. Lawrence III, The Id, the Ego, and Equal Protection: Reckoning with Unconscious Racism, 39 STAN. L. Rev. 317 (1987); Mari J. Matsuda, Voices of America: Accent, Antidiscrimination Law, and a Jurisprudence for the Last Reconstruction, 100 Y ALE L.J. 1329 (1991) [hereinafter Matsuda, Voices of America]; Mari Matsuda, Affirmative Action and Legal Knowledge: Planting Seeds in Plowed-Up Ground, 11 HARv. WoMEN's L.J. 1 (1988); Mari J. Matsuda, Looking to the Bottom: Critical Legal Studies and Reparations, 22 Harv. C.R.-C.L. L. Rev. 323 (1987); Gerald Torres, Critical Race Theory: The Decline of the Universalist Ideal and the Hope of Plural Justice-Some Observations and Questions of an Emerging Phenomenon, 75 MinN. L. Rev. 993 (1991); Gerald Torres, Local Knowledge, Local Color: Critical Legal Studies and the Law of Race Relations, 25 SAN DIEGo L. Rev. 1043 (1988); PATRIClA J. Williams, The Alchemy of Race and Rights (1991); Patricia J. Williams, Alchemical Notes: Reconstructing Ideals from Deconstructed Rights, 22 HARV. C.R.-C.L. L. REV. 401 (1987); Richard Delgado, Enormous Anomaly? Left-Right Parallels in Recent Writing About Race, 91 ColUm. L. Rev. 1547 (1991) [hereinafter Delgado, Enormous Anomaly?] (book review); Richard Delgado, Recasting the American Race Problem, 79 CALIF. L. Rev. 1389 (1991) [hereinafter Delgado, Recasting the American Race Problem] (reviewing Roy L. Brooks, Rethinking the American Race Problem (1990)); Richard Delgado, Mindset and Metaphor, 103 HARv. L. Rev. 1872 (1990); Linda S. Greene, "Breaking Form," 44 Stan. L. Rev. 909 (1992) (book review); Jon Wiener, Law Profs Fight the Power, The NAtion, Sept. 4/11, 1989, at 246. Not all of these scholars consider themselves to be CRT proponents.

4. In this article, we will use "classical-liberal" to refer not to liberalism in the partisan political sense but to the liberal tradition in political theory, as represented, for example, by figures like Rousseau, Locke, Mill, and Rawls. See infra note 44 (distinguishing "classical-liberal" and "classicliberal" civil rights scholarship).

5. 347 U.S. 483 (1954). For a discussion of FEO, see infra Part I.C.; see also RoY L. Brooks, Rethinking the American Race Problem 25-33 (1990) (discussing FEO).

6. See infra text accompanying notes 38-39.

7. See infra text accompanying notes $40-43$. 
little to the ordinary civil rights scholarship of classical-liberals. ${ }^{8}$ However, by adopting an approach that is more sensitive to the teachings of prominent CRT scholars (hereinafter "race crits"), we reach a different conclusion. Although race crits' own characterizations of CRT ${ }^{9}$ may exaggerate (and fail to specify adequately) the contributions that CRT can make to legal discourse, this Article will identify important ways that CRT can enrich or add to the traditional liberal account of civil rights law at both the macro- and microtheoretical levels.

At the macrotheoretical level, discussed in Parts I and II of the Article, we argue that CRT is innovative because it proceeds from a different assumption about the conceptual soundness of FEO. Whereas classical-liberals (including both traditionalists and reformists) approach civil rights from the perspective that FEO is conceptually sound, CRT takes the position that FEO is conceptually flawed. ${ }^{10}$ In other words, while classicalliberals are generally pleased with our existing civil rights policy and are committed to a symmetrical model of racial equality, CRT favors an asymmetrical ideal of racial equality which rejects race-blindness in favor of an "empowerment" model that permits taking affirmative steps to achieve a level playing field. ${ }^{11}$

We also find microtheoretical differences between CRT and classicalliberalism, although not in every instance. Parts III and IV of the Article apply the basic civil rights perspectives described in Parts I and II to five specific areas of civil rights law: equal protection law's standard of liability and standard of judicial review (Part III) and the Title VII subjects of accent discrimination and intersectionality, as well as the abolition of Title VII

8. In response to Duncan Kennedy, A Cultural Pluralist Case for Affirmative Action in Legal Academia, 1990 Duke L.J. 705 (arguing that hiring more black law professors will produce a new form of legal scholarship, which would be a welcome antidote to complacency and stagnation in traditional legal scholarship), Judge Posner argues that while there is some evidence that feminist legal scholarship has had this antidotal effect on law, it is unlikely that minority scholarship will have a similar impact. Richard A. Posner, Duncan Kennedy on Affirmative Action, I990 Duke L.J. 1I57, 1160. Posner goes on to assert that "Professor Kennedy does not mention a single idea that critical race theory has produced." Id. at I161. Both the tone and substance of Judge Posner's commentary have been criticized as "the pious, solipsistic demand of white authority and the right of ultimate control in the legal academy by one of this country's leading academicians and jurists." Culp, Posner on Duncan Kennedy and Racial Difference, supra note 3, at 1096-97. Moreover, Professor Culp adds, if Judge Posner chooses to comment on the merits of CRT "without engaging it," then he is "attempt[ing] to deny to black legal scholars the power to speak or the right to author their own discourse. . . [H]e is racist while claiming to be a neutral observer of racial circumstances in the legal academy." Id. at 1101 (footnote omitted). For additional defense of the value of CRT, sec Richard Delgado, The Inward Turn In Outsider Jurisprudence, 34 WM. \& MARY L. Rev. 741, 766 (1993) (suggesting that it is "too early" to evaluate CRT and that "CRT should devote its effort to critiquing social institutions, legal doctrine, and the culture of racism-not itself or its own members").

9. See supra note 3.

10. See infra Part II.A.

11. See infra text accompanying notes 50-59. 
itself (Part IV). We argue that CRT's deconstructive and reconstructive ${ }^{12}$ doctrinal analyses differ from those of classical-liberalism in all of these areas except intersectionality. ${ }^{13}$

Moreover, we emphasize that CRT's reconstructive proposals are not always more radically transformative than those of the classical-liberals. For example, the reformists' response to the intent test (advocating the adoption of an "effects test") is more radical than CRT's proposal (reformulating the intent test to focus on social "meaming"). ${ }^{14}$ However, while examples such as this underscore the need to avoid exaggerating the uniqueness of CRT, we conclude with a favorable overall evaluation of CRT's contribution to contemporary civil rights analysis.

12. The terms "deconstruction" and "reconstruction" carry different meanings depending upon the context in which they are used. For example, in the literary context, deconstruction most often denotes a theory of poststructuralism that criticizes the Westem philosophical belief in "logocentrism," which is "the concept of structure that depends on stabilizing, fixed, 'centers,' such as truth, God, consciousness, being, [and] essence, . . . and the inferior axiological oppositions, such as lie, Satan, unconscious, nonbeing, [and] appearance, ...." Gloria Stephenson, Deconstruction, in 1 Women's StUdIES ENCYCLOPEDIA: VIEWS fROM THE SCIENCES 89 (Helen Tierney ed., 1991). This concept of deconstruction is called "Derridean deconstruction," named after the French intellectual Jacques Derrida. Id.; see also A HANDBOoK to Literature 128-29 (C. Hugh Holman \& William Harmon eds., 6th ed. 1992) (defining deconstruction).

In the context of Critical Legal Studies, deconstruction refers to a method of legal analysis that reveals contradictions within legal texts and their referents. Such analysis demonstrates the "indeterminacy" and even political bias of legal rules. As used in this Article, the terms "deconstruction" and "reconstruction" refer to the contingency of legal analysis in civil rights scholarship. Critical and analytical arguments about legal principles, doctrine, or issues are "deconstructive" in that they are shaped (or "constructed") in large part by pre-existing macrotheoretical perspectives on civil rights. See infra Parts I, II for a discussion of such perspectives. Creative and solution-oriented arguments are "reconstructive" in that they are necessarily informed by the scholar's deconstructive analysis. Thus, civil rights analysis, we contend, is more of an interactive process (i.e., the facts and the law interact with the fundamental civil rights framework that the scholar brings to the table) than a linear or syllogistic process. Perhaps it can be said that all legal analysis proceeds or should proceed in an interactive manner. For example, Professor Bartlett observes:

When feminists "do law," they do what other lawyers do: they examine the facts of a legal issue or dispute, they identify the essential features of those facts, they determine what legal principles should guide the resolution of the dispute, and they apply those principles to the facts. This process unfolds not in a linear, sequential, or strictly logical manner, but rather in a pragmatic, interactive manner. Facts determine which rules are appropriate, and rules determine which facts are relevant.

Katharine T. Bartlett, Feminist Legal Methods, 103 Harv. L. Rev. 829, 836 (1990).

Of course, the question of whether to employ an interactive process instead of just a logical approach harkens back to Holmes' criticism of the legal formalism promoted by Christopher Columbus Langdell, the famous Harvard Law School Dean, in his contracts casebook. See Book Notice, 14 AM. L. Rev. 233, 234 (1880) (Holmes' unsigned review of Christopher Columbus Langdell, A Selection of Cases on the Law of Contracts, with a Summary of the Topics Covered by the Cases (2d ed. 1879)) ("No one will ever have a truly philosophic mastery over the law who does not habitually consider the forees outside of it which have made it what it is."); see also OLIVER W. HOLMEs, THE Common Law 5 (Mark D. Howe ed., Belknap Press 1963) (1881) "The life of the law has not been logic: it has been experience.").

13. See infra Part IV.B. (describing how the CRT analysis of intersectionality does not differ substantially from that of the reformists).

14. See infra text accompanying notes 103-04. 
I

\section{Formal Equal Opportunity and Its Predecessors}

\section{A. Formal Equal Opportunity (FEO)}

Formal equal opportunity (FEO) has been our nation's fundamental civil rights policy since Brown v. Board of Education. ${ }^{15}$ Essentially, this policy reflects the idea that the State is required, by the equal protection provisions of the Fifth and Fourteenth Amendments, to act in an evenhanded manner toward the races. However, to understand FEO more completely, it will be helpful to consider its two historical predecessors: the "separate-and-unequal" and "separate-but-equal" policies.

\section{B. Predecessor Civil Rights Policies}

Our nation's first "civil rights" policy, separate-and-unequal, arose with the institution of slavery. ${ }^{16}$ Under this policy, the races were kept separate and unequal with whites being placed in positions superior to those of African Americans. Accordingly, African Americans had no legal rights in interactions with whites, not even the procedural right to sue whites in federal court as citizens of the United States. ${ }^{17}$

Without a doubt, white racism (the belief in white superiority) ${ }^{18}$ was the primary motivation behind the separate-and-unequal policy. As the Supreme Court stated unabashedly in Dred Scott $v$. Sandford, even emancipated African Americans were considered "beings of an inferior order, and altogether unfit to associate with the white race, either in social or political relations; and so far inferior, that they had no rights which the white man was bound to respect."19

Toward the end of the nineteenth century, the separate-and-unequal policy was replaced with a new civil rights blueprint: "separate-but-equal." Also known as the "Jim Crow" civil rights approach, ${ }^{20}$ this policy was a distinct improvement over its predecessor; it at least granted African Americans some constitutional rights, albeit fewer than were enjoyed by

15. 347 U.S. 483 (1954).

16. See generally John H. Frankin, From Slavery to Freedom: A History of Neoro AMERICANS 71-343 (3d ed. 1967) (tracing the history of slavery in America); A. LEON HioaingothaM, Jr., In the Matter of Color: Race and the American legal Process-The Colonial Period 3310, 371-95 (1978) (same).

17. See Dred Scott v. Sandford, 60 U.S. (19 How.) 393 (1857) (holding that an emancipatcd slave is not a "citizen" of a state for purposes of fcderal diversity jurisdiction). See generally Don $\mathrm{E}$. Fehrenbacher, The Dred Scott Case: Its Sianificance in American Law and Polmitics (1978).

18. Webster's New Collegiate Dictionary 969 (9th ed. 1983) (defining "racism" as "a bclief that race is the primary determinant of human traits and capacities and that racial differenccs produce an inherent superiority of a particular race"). For a discussion of CRT's concept of "racism," see infra text accompanying notes $47-49$.

19. 60 U.S. (19 How.) at 407.

20. See, e.g., Juan Williams, Eyes on the Prize: America's Civil Riohts Years, 1954-1965, at 9-10 (1987); C. VanN Woodward, The Strange Career of Jim Crow 140 (2d. rev. ed. 1966). 
whites. Embraced by the Supreme Court in Plessy v. Ferguson, ${ }^{21}$ the separate-but-equal policy allowed separation of the races, as long as they were treated equally once separated. With more than a wink and a nod, the federal and state governments authorized racial segregation and discrimination in public scliools, libraries, restrooms, public accommodations, places of employment, and other areas of American life. ${ }^{22}$ Florida even went so far as to enact a law that required " 'school textbooks used by one race ... to be stored separately from those used by the other race." "23 In short, under the separate-but-equal policy, African Americans were legally locked out of mainstream society by a system of apartheid that controlled all aspects of life in the South ${ }^{24}$ and by a looser but still prominent form of racial segregation in the North. ${ }^{25}$

Like the separate-and-unequal policy, the separate-but-equal policy was motivated by racism. The prevailing academic view of African Americans at the time is reflected in the following comments:

No savant anywhere in the western world arose to challenge the conclusion of the famous 1910 edition of Encyclopaedia Britannica, assembled under the supervision of the faculties of Oxford and Cambridge: ". . . the negro would appear to stand on a lower evolutionary plane than the white man, and to be more closely related to the highest anthropoids."26

That the separate-but-equal racial paradigm was morally bankrupt seems clear beyond peradventure. However, correctly sensing that white America and the American judiciary were not ready to acknowledge this fact, the National Association for the Advancement of Colored People (NAACP) eschewed a direct legal attack on the morality of the separatebut-equal policy in favor of an attack on the "equality" part of the policy.

21. 163 U.S. 537 (1896), overruled by Brown v. Board of Educ., 347 U.S. 483 (1954).

22. See, e.g., Brooks, supra note 5, at 25-26 (noting that a "parade of laws" designed to enforce the separate-but-equal policy followed soon after Plessy); John H. Franklin, History of Racial Segregation in the United States, 304 ANnals AM. ACAD. Pol. \& Soc. ScI. 1, 6-9 (1956) (noting that Jim Crow segregation laws expanded considerably in the late nineteenth and earlier twentieth centuries and that "[t]he supply of ideas for new ways to segregate whites and Negroes seemed inexhaustible"); Wiluiams, supra note 20 , at 10 (describing some types of discrimination that preceded, and were embraced by, Plessy).

23. Robert A. Margo, Race and Schooling in the South, 1880-1950: An Economic History 70 (1990) (quoting Charles A. Lofgren, The Plessy Case: A Legal-Historical INTERPRETATION 202 (1987)).

24. See generally WoODWARD, supra note 20 (containing a thorough discussion of the Jim Crow era).

25. Describing his first visit to the North in the 1930s, one white southerner observed: "Proudly cosmopolitan New York was in most respects more thoroughly segregated than any Southern city; with the exception of a small coterie of intellectuals, musicians, and entertainers there was little traffic between the white world and the black enclave in upper Manhattan called Harlem." HARRY S. Ashmore, Hearts and Mands: The Anatomy of Racism from Roosevelt to Reagan 37 (1982); cf. Franklin, supra note 22, at 1-2 (describing pre-Civil War racial segregation in the North).

26. AsHMORE, supra note 25 , at 44 . 
Thus, beginning in the $1920 \mathrm{~s}$, the NAACP initiated protracted litigation to force an equalization of public scliool expenditures in the South.

Using the researcll of African American scholars like W.E.B. DuBois, ${ }^{27}$ Horace Mann Bond, ${ }^{28}$ and Charles Johnson, ${ }^{29}$ as well as research by white scholars like Gunnar Myrdal, ${ }^{30}$ NAACP lawyers were able to document substantial racial inequality in per pupil expenditures, teacher salaries, and working conditions throughout the South, even between African American and white schools in the same school district. ${ }^{31}$ With such evidence in hand, the NAACP began to win equalized-funding cases against local school boards and public universities. ${ }^{32}$ These victories made the separate-but-equal policy an expensive proposition for segregationists. Although the increasing costliness of segregation compelled some segregationists to rethink the feasibility (if not the morality) of the separate-butequal policy, it was the fortuitous confluence of this economic pressure and several noneconomic forces that ultimately led to the demise of the Jim Crow policy.

Public opinion was the most important of these noneconomic factors. The public's view on interracial relations began to change, and the separatebut-equal policy was increasingly rejected during the $1940 \mathrm{~s}$. The rise of global Nazism, fascism, and communism helped to accelerate this change of opinion; fighting for freedom abroad made denying freedom at home seem lypocritical and cruel, and tainted the United States' reputation abroad. In addition, the nuorality of the separate-but-equal policy was

27. See, e.g., W.E.B. DuBois \& Augustus G. Dill, The Common School and the Negro AMERICAN (1912).

28. See, e.g., Horace M. Bond, The Education of the Negro in the American Social Order (1934); Horace M. Bond, Negro Education in Alabama: A Study in Cotton and Steel (1939).

29. See, e.g., Charles S. Johnson, Shadow of the Plantation 129-49 (1934).

30. Gunnar myrdal, an american Dilemma: The Negro Problem and Modern Democracy 318-20, 337-44, 879-907 (20th Anniversary ed. 1962) (1944).

31. For example: "The typical black teacher labored in a poorly equipped classroom, taught larger classes for fewer days per year, and earned less doing it than did her white counterpart." MARGO, supra note 23, at 56. Likewise, "[i]n the Deep South states of Louisiana and Mississippi [in 1890], black teachers earned about 80 percent of what white teachers earned." Id. at 54; see also JAMES D. Anderson, The Education of BLACKs In THE South, 1860-1935, at 110-278 (1988) (discussing the forms of education available to African Americans in the South and the drawbacks of these programs); Thurgood Marshall, Teachers' Salary Cases, in The Negro HandBooK 1946-1947, at 40-50 (Florence Murray ed., 1947) (discussing the disparities in salary between African American and white teachers and reviewing court cases brought to remedy the disparities).

32. See, e.g., Sweatt v. Painter, 339 U.S. 629 (1950) (ordering that an African American student be admitted to the all-white University of Texas Law School on the ground that the state law school established for African Americans failed to offer equal educational opportunities); McLaurin v. Oklahoma State Regents for Higher Educ., 339 U.S. 637 (1950) (holding that state-imposed rcstrictions placed on African American graduate students attending an otherwise all-white university produced such inequalities as to offend equal protection); Alston v. School Bd., 112 F.2d 992 (4th Cir.), cert. denied, 311 U.S. 693 (1940) (holding that African American teachers cannot arbitrarily be paid less than equally qualified white teachers); see also Missouri ex rel. Gaines v. Canada, 305 U.S. 337 (1938) (relying on the separate-but-equal doctrine to hold that an African American citizen of Missouri must be admitted to the state's all-white law school rather than be forced to attend an out-of-state law school). 
called into question by the need for African American labor at home to help with the war effort ${ }^{33}$ and by the worldwide embarrassment that resulted when American citizens discriminated against African dignitaries who were in our country to attend United Nations functions.

Although the combination of these various forces convinced some segregationists of the need to jettison the separate-but-equal policy, other more determined segregationists simply replaced their strategy of total defiance with one of partial resistance. They were willing to give greater attention to the "equal" part of the separate-but-equal policy in order to hold on to the "separate" part. A measure of economic equality could be tolerated as long as the races did not have to mix. But it was too late. Sensing a change in public opinion, the NAACP adopted a new legal strategy: instead of basing its attack on the "equal" part of the formula, which virtually conceded the theoretical legitimacy of the policy, the NAACP now attacked the policy en toto, arguing that true racial equality is fundamentally incompatible with de jure segregation. ${ }^{34}$ This strategy culminated in 1954 with the NAACP's victory in Brown v. Board of Education. ${ }^{35}$

\section{The Concept of FEO}

Signaling the end of three and one-half centuries of de jure and de aequitate racial segregation and discrimination, Brown gave birth to our current civil rights policy: formal equal opportunity (FEO). At its most basic level, FEO can be defined as a civil rights policy which requires that all Americans, regardless of race or color, are to have equal legal status. Such a policy seems essential if America shall ever become a racially symmetrical society. Thus, while the separate-but-equal policy sanctioned a society dominated by whites, FEO envisions a society in which the races are symmetrically situated. In furtherance of this social goal, the law must treat all groups, including historically excluded groups, without reference to race or color and must, in addition, prefer racial integration over racial separation. Hence, FEO incorporates two policies-colorblindness and racial mixing - and uses them as vehicles for achieving its social agenda, the creation of a racially symmetrical society. ${ }^{36}$

33. See Brooks, supra note 5 , at 28.

34. The change in litigation strategy took effect at the trial level in Briggs v. Elliott, $98 \mathrm{~F}$. Supp. 529 (E.D.S.C. 1951), vacated, 342 U.S. 350 (1952), where one of the district court judges, Waties Waring, suggested that the case be dismissed without prejudice to allow Thurgood Marshall to refile the case as an attack on the constitutionality of racial segregation rather than as a constitutional challenge based merely on equal facilities. See Richard Kiuger, Simple Justice: The History of Brown $v$. Board of Education and Black America's Struggle for Equality 304 (Vintage Books 1977) (1975). Briggs was one of four cases consolidated in Brown v. Board of Education. See Brown v. Board of Educ., 347 U.S. 483, 486 n.1 (1954).

35. 347 U.S. 483 (1954).

36. See Brooks, supra note 5, at 29-30 (emphasizing that FEO is comprised of two major tenets: race-neutral legal treatment and its "sibling tenet," racial integration). 
Referring to education, a nineteenth century Kansas court captured the value of a symmetrical model of racial equality:

At the common schools, where both sexes and all kinds of children mingle together, we have the great world in miniature; there they may learn human nature in all its phases, with all its emotions, passions and feelings, its loves and hates, its hopes and fears, its impulses and sensibilities; there they may learn the secret springs of human actions, and the attractions and repulsions, which lead with irresistible force to particular lines of conduct. But on the other hand, persons by isolation may become strangers even in their own country; and by being strangers, will be of but little benefit either to themselves or to society. As a rule, people cannot afford to be ignorant of the society which surrounds them; and as all kinds of people must live together in the same society, it would seem to be better that all should be taught in the same schools. ${ }^{37}$

In the years since Brown, laws that prohibit segregation and discrimination on the basis of race or color in employment, voting, housing, and other areas of American life have been enacted to vindicate the FEO policy. $^{38}$ One brand of classical-liberals, the traditionalists, applaud these developments as evidence of FEO's sound intellectual framework and effective implementation. Stated differently, these traditionalists embrace FEO in both concept and operation. ${ }^{39}$

37. Board of Educ. v. Tinnon, 26 Kan. 1, 19 (1881).

38. See, e.g., Civil Rights Act of 1964, 42 U.S.C. $\$ \S 1971$, 1975a-1975f, 2000a to 2000h-6 (1988 \& Supp. IV 1992); Voting Rights Act of 1965, 42 U.S.C. $\S \S 1971,1973$ to $1973 f f-6$ (1988 \& Supp. IV 1992); Fair Housing Act of 1968 (Title VIII), 42 U.S.C. $\S \S 3601-3619,3631$ (I988 \& Supp. IV 1992).

39. The late Professor Alexander Bickel is the intellectual and spiritual leader of the traditionalists. Perhaps his most famous book, The Morality of Consent, written in 1975, is often cited by traditionalists. See, e.g., City of Richmond v. J.A. Croson Co., 488 U.S. 469, 521,527 (1989) (Scalia, J., concurring in the judgment). When applying FEO, traditionalists, unlike reformists, usually favor liberty over equality, colorblindness over color-consciousness, and integration over separation. Traditionalists also reject "the pervasive view that the Federal Constitution must address all ills in our society." Hudson v. McMillian, 112 S. Ct. 995, 1010 (1992) (Thomas, J., dissenting). For a more detailed discussion of traditionalism, see Roy L. Brooks ET AL., CiviL Rights LmTGATION: CASES AND Materials For a Multicultural Soctety, ch. 1 (forthcoming 1995) [hereinafter Brooks, Civil Rights Lmgation]. It might be useful to note that Judge Posner, Richard Epstein, and other law-andeconomics scholars do not employ the traditionalist perspective in their civil rights writings. Traditionalists believe in FEO and its implementing legislation. Law-and-economics scholars, with their brand of libertarianism, may believe in FEO in some theoretical sense but not to the extent of government support as policy or law. These scholars would, in other words, overturn civil rights legislation and most other forms of federal legislation in order to promote the economic liberty of private property and free markets. For such scholars, laws banning discrimination are problematie because "[i]f it is appropriate for the state to say that individuals may not discriminate in employment because of color or race or religion, then it is equally appropriate for the state ... to say that individuals must discriminate in employment on the basis of color, race or religion." MiLTon FrIedMan, CAPTALISM AND FREEDOM 113 (1962). Also, the market protects against racial discrimination because "[a] businessman or an entrepreneur who expresses preferences in his business activities that are not related to productive efficiency is at a disadvantage compared to other individuals who do not." Id. at 109. Finally, antidiscrimination laws may be economically inefficient. Richard A. Posner, The 
Yet, when compared to the living conditions of whites, the living conditions of racial minorities, especially African Americans, have not improved substantially since $1954 .^{40}$ This disparity is one of the primary concerns of the other group of classical-liberals, the reformists. Hence, although reformists share the traditionalists' belief in the conceptual validity of FEO, the sluggish socioeconomic progress of racial minorities since Brown, which has impeded progress toward a racially symmetrical society, has led reformists to reject the traditionalists' claim that FEO has been effectively implemented.

Reformists argue that the persistence of racial inequalities decades after Brown is partially due to the faulty manner in which traditionalist courts and legislatures have applied the FEO principle. ${ }^{41}$ Since Brown, the reformists claim, FEO has been implemented in ways that subordinate African Americans and other racial minorities. ${ }^{42}$ Thus, since they believe that FEO is conceptually sound but operationally flawed, reformists einphasize the need to execute FEO more effectively by giving greater deference to the civil rights of racial minorities. ${ }^{43}$

Like reformists, race crits are also greatly concerned about the rate of racial progress decades after Brown. Unlike reformists, however, race crits believe that the conceptual framework of FEO is at least partially responsible for the lack of substantial progress on racial matters. Accordingly, race crits argue that the principle of FEO, particularly its syminetrical model of racial equality, nust be rejected altogether. We elaborate on this civil rights perspective next.

Efficiency and the Efficacy of Title VII, 136 U. PA. L. Rev. 513, 515-16 (1987). At one time, Epstein believed in FEO and at least one of its implementing pieces of legislation, namely Title VII: "Title VII was heaven-sent [in the days of Jim Crow]." Richard A. Epstem, Forbidden Grounds: The Case Against EMployment Discrimination Laws 251 (1992). This would clearly place Epstein in the traditionalist camp, at least on the issue of Title VII, except that Epstein now believes that Title VII, may have outlived its usefulness. See id. at 497. Law-and-economics scholars fail to see that "efficiency is not a logically dependent proxy for doing nothing," Edward J. McCaffery, Slouching Towards Equality: Gender Discrimination, Market Efficiency, and Social Change, 103 YALE L.J. 595, 648 (1993), and, more seriously, they discount or ignore the harms to dignity that victims of discrimination suffer. Because of the latter, race crits would probably label law-and-economics scholars "racists." See supra note 8. Alternatively, law-and-economics scholars may simply be "racial agnostics." For a detailed discussion of law-and-economics in the civil rights context, see Brooks, Crvil Rights Litigation supra, ch. $4 \mathrm{~B}$.

40. See generally Brooks, supra note 5, at 34-128 (providing a detailed analysis of economic and social disparities between African Americans and whites).

41. See, e.g., id. at 32-33 (criticizing the application of FEO and contending that equal opportunity still does not exist).

42. Id. at 4-5, 51-66, 127-28; Alan D. Freeman, Legitimizing Racial Discrimination Through Antidiscrimination Law: A Critical Review of Supreme Court Doctrine, 62 MinN. L. Rev. 1049 (1978).

43. See BrooKs, supra note 5, at 32 ("The real problem with the application of formal equal opportunity . ... is the lack of priority given to African American civil rights interests . ..."); see also Brooks, supra note 39 , ch. 1. Reformists believe that FEO must be applied with greater deference to racial minorities' civil rights if the latter are to experience measurable equal legal treatment. See Brooks, supra note 5, at 150-70 (suggesting several ways in which FEO can be redeployed in a nontraditionalist manner to achieve its policy objectives more effectively). 
II

MaCrotheoretical Differences: CRT and ClassicalLIBERALISM

\section{A. CRT's Criticisms of FEO}

Leading race crits have been highly critical of both the "traditionalist" and "reformist" varieties of classical-liberal scholarship. Not surprisingly, race crits dispute the traditionalists' claim that FEO has adequately protected racial minorities' civil rights since Brown. More radically, however, race crits also criticize reformist scholars, who are willing to concede that FEO has been applied ineffectively, for defending the conceptual validity of FEO. Professor Richard Delgado, one of the most prolific legal scholars in the nation and a leading race crit, comments: "[Reformist] writing, generally highly normative and rights-based in nature but cautiously incremental in scope and ambition . . . accepts the dominant paradigm of civil rights scholarship and activism, and urges that we work harder . . . within that paradigm." 44 Thus, race crits attack reformists for advocating piecemeal social reform and continued loyalty to the FEO principle instead of radical social transformation. The reformists' approach is inadequate, race crits insist, because FEO inevitably makes for bad civil rights policy. ${ }^{45}$

Arguing that FEO is conceptually flawed, race crits emphasize that the liberals' policy reacts only to the most obvious and grotesque forms of racism, whereas most forms of racism are deeply embedded in the framework of our society. According to race crits, racism is "normal science" in American society, and most forms of racism go unnoticed under FEO. As Professor Delgado states:

Formal conceptions of equality treat racism as an anomaly, an illness, a sort of cancer on an otherwise healthy body. They are aimed at deviations from a status quo or baseline assumed to represent equality. If we spot such a deviation, we punish it. But most racism is not a deviation. As a number of Critical writers have been pointing out, racial subordination is an ordinary, "normal" feature of our social landscape. It is "normal science"-the ordinary state of affairs. Because racism is an ingrained feature of our cultural landscape, it looks ordinary and natural to everyone in that culture. It is "the way things are." Formal equal opportunity is thus calculated to remedy at most the more extreme and shocking forms of racial treat-

44. Delgado, Enormous Anomaly?, supra note 3, at 1547-48 (footnotes omitted). We have labeled as "reformist" the scholarship that Professor Delgado calls "classic-liberal." Hence, our broader category of "classical-liberal" civil rights scholarship includes both "classic-liberal" ("reformist") and "traditionalist" civil rights scholarship. See supra note 4.

45. See Delgado, Recasting the American Race Problem, supra note 3, at 1393, 1400 (arguing that "neutral principles are incoherent and doomed to replicate, not remedy, white-over-black domination" because racism is pervasive and conventional interpretations of racism perpetuate status quo racial subordination). 
ment; it can do little about the business-as-usual types of racism that people of color confront every day and that account for much of our subordination, poverty, and despair. ${ }^{46}$

As this passage suggests, the race crits' conception of "racism" is crucial to an understanding of CRT in general and of CRT's rejection of FEO in particular. The race crits' conception of racism is evident in a famous statement made by Anthony Downs while appearing before the United States Civil Rights Commission:

Racism is one of those words that many people use, and feel strongly about, but cannot define very clearly. Those who suffer from racism usually interpret the word one way while others interpret it quite differently....

Perhaps the best definition of racism is an operational one. This means that it must be based upon the way people actually behave, rather than upon logical consistency or purely scientific ideas. Therefore, racism may be viewed as any attitude, action, or institutional structure which subordinates a person or group because of his or their color. Even though "race" and "color" refer to two different kinds of human characteristics, in America it is the visibility of skin color-and of other physical traits associated with particular color or groups-that marks individuals as "targets" for subordination by members of the white majority. This is true of Negroes, Puerto Ricans, Mexican Americans, Japanese Americans, Chinese Americans, and American Indians. Specifically, white racism subordinates members of all these other groups primarily because they are not white in color, even though some are technically considered to be members of the "white race" and even view themselves as "whites." 47

Thus, the race crits define racism in both "substantive" and "procedural" terms. ${ }^{48}$ It is not simply attitudes or traditional racism (the belief in white superiority) ${ }^{49}$ that draws the race crits' attention; it is also individual or institutionalized behavior that has the effect of subordinating persons of color to whites. For example, racism is not so much overt racial hatred as it is the subconscious assuniption made by some whites that an African American man walking in a white neighborhood is a dangerous criminal or is otherwise up to no good.

46. Id. at 1393-94 (footnotes omitted); see also DeRrICK BeLL, FACES AT the Bottom of the Well: The Permanence of Racism (1992).

47. Anthony Downs, Racism in America and How to Combat It, UNTTED States Commission on Crvil Rights 5 (1970) (emphasis added). That Anthony Downs is white may be of significance to some.

48. See, e.g., Delgado, When a Story Is Just a Story, supra note 3, at 104-06.

49. See supra notes 18-19 and accompanying text. 
Race crits believe that classical-liberals and their FEO policy fail to address these subtle aspects of racism. They believe FEO has a fundamental conceptual flaw above and beyond its operational problems. FEO, the race crits argue, has only a philosophical attachment to equal opportunity and, as a result, it does not go far enough to redress the day-to-day problems of racial minorities. It is not enough, in other words, to simply alter the legal status of African Americans or to otherwise enjoin future racial discrimination; these approaches ignore the damage caused by past and lingering racism. A commitment to redress such damage must be built permanently into any modern civil rights policy. FEO has failed and will continue to fail because it lacks this commitment.

Race crits also attack FEO for erroneously assuming the possibility and desirability of racial sameness, or equal legal treatment, and for ignoring legally significant differences between African Americans and whites. It is wrong, CRT emphasizes, to treat the races as if they are symmetrically situated with regard to a legal rule, doctrine, policy, or practice when in fact they are not. African Americans, for example, are burdened by a history and continuing reality of racial oppression and subordination that whites do not share. ${ }^{50}$

Finally, race crits argue that FEO privileges white values over African American or other "outsider" values. For example, African American children are bussed to white schools and not vice versa because it is automatically assumed that white schools are "better" than African American schools. ${ }^{51}$ Equal treatment as envisioned by FEO also means that minorities are to be subjected, albeit in the "same" manner as whites, to terms and conditions that were established long ago by whites. Thus, under FEO, a law school can legally dismiss an African American tenured professor who remains on leave beyond a certain period of time-determined by whites in accordance with their own values-to protest the law school's "racist" hir-

50. See the discussion of FEO's discriminatory predecessor policies, separate-and-unequal and separate-but-equal, supra Part I.B. Likewise, consider Washington v. Davis, 426 U.S. 229 (1976), discussed infra text accompanying notes 65-66. According to one scholar, the poor performance of African Americans on the civil service test "could easily be traced to the history of racial discrimination in [Washington D.C.'s] school system." Charles R. Lawrence III, "Justice" or "Just Us": Racism and the Role of Ideology, 35 STAN. L. REv. 831,849 n.69 (1983) (book review).

51. The Feagins have argued that school integration under FEO has taken shape as "one-way" integration. African Americans must adopt white instifutions and conventions, but there is no expectation that whites must jettison their institutions and conventions in favor of African American schools and culture. See Joe R. Feagin \& Clairece Booher Feagin, Racial and Ethinic Relations 250-53 (4th ed. 1993). Thus, equal treatment means assimilation, and assimilation means onc-way integration. Why has one-way integration been adopted? CRT would argue that one-way integration results from society's privileged treatment of "whiteness." See, e.g., Cheryl I. Harris, Whiteness as Property, 106 HARv. L. Rev. 1709, 1715 (1993) (contending that "whiteness" has become a form of property and has, as a result, allowed for "the legal legitimation of expectations of power and control that enshrine the status quo as a neutral baseline, while masking the maintenance of white privilege and domination"). 
ing practices. ${ }^{52}$ Even though protest and self-help are deeply held values among African Americans, FEO deems them "irrelevant" to the law school's decision. In principle, then, FEO requires only that the African American faculty member be treated the "same" way the law school would treat a white faculty member under "similar" circumstances. However, because such rules, which must now be applied "equally," were originally created by whites, FEO's symmetrical conception of racial equality merely perpetuates an existing pro-white bias.

Given these criticisms of the classical-liberals' FEO policy, the questions then become: What type of fundamental civil rights policy would CRT prefer? What is CRT's alteruative vision of racial equality? We address these questions next.

\section{B. Racial Empowerment: CRT's Conception of Equality}

Race crits have been concerned far more with deconstruction than reconstruction. ${ }^{53}$ For example, they have been far more vocal in criticizing the hidden racial biases of seemingly neutral laws than in articulating a program for reforming those laws. Likewise, CRT has failed to develop or describe its own conception of racial equality. This relative lack of reconstructive proposals may be attributable to the race crits' belief that meaningful legal reform will not happen in the foreseeable future. ${ }^{54}$ But this would not justify complete abandonment of the reconstructive project. ${ }^{55}$ Perhaps, then, CRT's silence stems from a belief that racial equality will never be achieved through the law. ${ }^{56}$ This explanation also seems inadequate, how-

52. For example, in 1990, Professor Derrick Bell took an unpaid leave of absence from Harvard Law School to protest the law school's failure to hire its first woman of color in a tenured faculty position. Professor Bell failed to change Harvard's hiring practices, and was dismissed when Harvard refused to extend his leave of absence. See, e.g., Josh Getlin, Raising Hell for a Cause, L.A. TIMES, Nov. 5, 1992, at E1.

53. See supra note 12 .

54. See generally BEL, supra note 46.

55. One of the authors of this Article, a reformist who shares CRT's skepticism regarding the proximity of meaningful reform, has nonetheless proposed several legal and economic reforms. See Brooks, supra note 5, at 2 ("African Americans cannot rely on the government to come through, to do what government must do to help overcome the obstacles racial minorities face in the United States."), 150-70 (suggesting reforms).

56. See Robin D. Bames, Realist Review, 24 Conn. L. Rev. 553, 553 (1992) (reviewing Derrick Bell, Racial Realism, 24 CoNN. L. REv. 363 (1992), and noting that Bell's article urges racial minorities to "abandon the ideal that racial equality can be obtained through law"). In Racial Realism, Professor Bell claims that "many will wish to deny, but none can refute" the following statement:

Black people will never gain full equality in this country. Even those herculean [sic] efforts we hail as successful will produce no more than temporary "peaks of progress," short-lived victories that slide into irrelevance as racial patterns adapt in ways that maintain white dominance. This is a hard-to-accept fact that all history verifies. We must acknowledge it and move on to adopt policies based on what I call: "Racial Realism."

Derrick Bell, Racial Realism, 24 ConN. L. Rev. 363, 373 (1992) (emphasis omitted); see also BeLL, RACE, RACISM AND AMERICAN LAw, supra note 3, at 60-63 (advocating "a new racial realism"). Racial Realism is a logical conclusion to Professor Bell's longstanding assessment of the effectiveness of American civil rights laws. One of Professor Bell's lasting contributions to our understanding of civil 
ever, since most race crits still seem to be committed to some manner of legal reform (or they have chosen a strange audience-law review readers). The most plausible explanation would seem to be that race crits have been so busy attacking on the deconstructive front, which is, after all, a main focus of "critical" race theory, that they have focused less on developing reconstructive proposals.

Regardless of the reasons for the race crits' relative reconstructive silence, it is clear that CRT is an incomplete theory without an articulated vision of racial equality. We shall, in this Section, attempt to fill that void by describing a conception of racial equality that is consistent with CRT scholarship.

Given their criticism of FEO, race crits necessarily must favor an "asymmetrical" conception of racial equality. Unlike symmetrical models of racial equality, which require that the races be treated the same no matter what,, 57 asymmetrical models assume the possibility and desirability of racial differences. Parallelling their deployment in theories of sexual equality, asymmetrical models of racial equality hold that the races are "often asymmetrically located in society" and reject "the notion that all [racial] differences are likely to disappear, or even that they should." cal equality refuses to condition the success of racial minorities on their adopting the behaviors, values, and appearances of white Americans.

Another basic feature of asymmetrical equality is its focus on creating a society in which social burdens and advantages are ultimately distributed proportionately between the races. Implicit in this is a recognition that a degree of racial imbalance-that is, racial empowerment-must be tolerated in order to reach this state of racial balance. Without racial empower-

rights law is his "interest-convergence" thesis, which posits that white Americans, including lawmakers and policy makers, will make significant advancements toward racial justice only when doing so will further their own interests (i.e., only when the interests of racial minorities and whites converge). See, e.g., BeLL, AND WE ARE Not SAVED, supra note 3, at 51-74 (expressing this thesis through a narrative); BEL., RACE, RACISM AND AMERICAN LAW, supra note 3, at 2-44 (providing evidence for the thesis in the context of slavery and the Civil War period); Derrick A. Bell, Jr., Brown v. Board of Education and the Interest-Convergence Dilemma, 93 HARv. L. REv. 518, 523-26 (1980) (discussing the intcrestconvergence thesis and drawing on the circumstances surrounding the Brown dccision for support).

Given the interest-convergence thesis, it is difficult to understand Professor Bell's happy ending in And We Are Not Saved. As Professor Richard Delgado has observed: "The gap between the bleak picture ... and the rosy ending is puzzling." Richard Delgado, Derrick Bell and the Ideology of Racial Reform: Will We Ever Be Saved?, 97 Y ALE L.J. 923, 927 (1988). Racial Realism answers the question posed in the title of Professor Delgado's article in the negative and seems to provide a more logical ending to Professor Bell's book. Professor Bèll's "Racial Preference Licensing Act," diseussed infra Part IV.C., is a logical extention of racial realism.

57. See Christine A. Littleton, Reconstructing Sexual Equality, 75 CALIF, L. Rev, 1279, 1291 (1987) (contending that in the context of sexual equality, the "symmetrical" approach "classifies asymmetries as illusions, 'overbroad generalizations,' or temporary glitches that will disappear with a little behavior modification").

58. Id. at 1292 . 
ment, there will always be an unnatural and unhealthy racial differential. ${ }^{59}$ Racial empowerment is the only way to neutralize unconscious racial discrimination in American culture. By encouraging us to respect racial differences, racial empowerment validates the life experiences of minorities.

The preceding analysis indicates that CRT contributes a unique macrotheoretical perspective to civil rights law. Unlike traditionalists and reformists, CRT rejects FEO at the normative level in favor of a civil rights policy that is more cognizant of the current and, according to CRT, future unequal distribution of societal advantages and disadvantages between whites and racial minorities and, more generally, between "in-groups" and "out-groups." Thus, unlike traditionalists and reformists, race crits would embrace the "empowerment" conception of racial equality described above as a necessary response to contemporary social realities.

Given that CRT offers a unique macrotheoretical perspective, ${ }^{60}$ the question arises whether this perspective translates into concrete microtheoretical differences. That is, when it comes to the analysis of specific rules of law or the articulation of legal reforms, are there differences between CRT and classical-liberalism? We shall examine this question within the context of two important areas of civil rights law: equal protection (Part III) and Title VII (Part IV).

\section{III}

\section{Microtheoretical Differences: Equal Protection Law}

The constitutional right to equal protection derives from two sources: the Equal Protection Clause of the Fourteenth Amendment and the equal protection component of the Due Process Clause of the Fifth Amendment. While the former protects against state action (or private action conducted "under the color of state law") that denies "the equal protection of the laws," the latter protects against federal action that works a similar deprivation. ${ }^{61}$ The provisions are otherwise coextensive. ${ }^{62}$

Using equal protection law as a basis for comparison, we shall attempt to examine whether CRT"s unique "empowerment" conception of racial equality can generate specific legal analyses that are different from those

59. For a discussion of wage, occupational, housing, educational, and other racial differentials, see Brooks, supra note 5, at 45-51, 70-74, 76-82, 117-27.

60. The macrotheoretical differences between CRT and classical-liberalism can be diagrammed as follows:

1. Classical-Liberalism*

a. Traditionalists

2. CRT**

b. Reformists

*Favors symmetrical racial equality.

FEO CONCEPT FEO IMPLEMENTATION

**Favors asymmetrical racial equality ("empowerment").

61. U.S. Const. amends. V, XIV, §1.

$\begin{array}{cc}\text { Sound } & \text { Sound } \\ \text { Sound } & \text { Unsound } \\ \text { Unsound } & \text { Unsound }\end{array}$

62. See United States v. Paradise, 480 U.S. 149, 166 n.16 (1987). 
suggested by classical-liberalism. We shall, in particular, compare CRT and classical-liberal scholarship regarding the standard of liability (Section A) and the standard of judicial review (Section B) in equal protection law.

\section{A. The Standard of Liability}

\section{Traditionalists' Argument for the Intent Test}

The modern standard of liability in equal protection cases is the "intent test." A product of the traditionalist interpretation of the Equal Protection Clause, the intent test requires that a plaintiff, in order to successfully bring an equal protection challenge against a state or federal law, must prove the existence of a discriminatory animus behind the law. Such proof must be presented even if the law has an outrageously exclusionary effect on the plaintiff's protected class. For example, African Americans who bring an equal protection challenge against a municipal land use law that has an exclusionary effect on their protected class must prove that the municipality in question enacted the law with the specific intent to exclude African Americans. Absent proof of such discriminatory intent, if the land use law is "facially neutral" as to race (i.e., if it does not contain an explicit racial classification like those that were prevalent in the days of Jim $\mathrm{Crow}^{63}$ ), the law will not be struck down as racially discriminatory. ${ }^{64}$

Washington v. Davis, ${ }^{65}$ a 1976 Supreme Court decision, is the seminal case on the "intent test" standard of liability. African American applicants, whose rate of failure on a written police examination was significantly higher than that of white applicants, filed a lawsuit claiming that the exam was racially discriminatory in violation of the Fourteenth Amendment's Equal Protection Clause. Disagreeiug with the D.C. Circuit, which at that time maintained that disproportionate effects standing alone will suffice to prove racial discrimination, the Supreme Court said that "to the extent that those cases rested on or expressed the view that proof of discriminatory racial purpose is unnecessary in naking out an equal protection violation, we are in disagreement." 66 This intent standard has been upheld in subsequent Supreme Court decisions. ${ }^{67}$

63. See supra text accompanying notes 20-35.

64. See, e.g., James v. Valtierra, 402 U.S. 137, 141 (1971). On the other hand, state regulation may discriminate on the basis of economic status, but such discrimination (if lacking discriminatory intent) does not merit constitutional protection. See, e.g., Dandridge v. Williams, 397 U.S. 471, 484-87 (1970); Jefferson v. Hackney, 406 U.S. 535, 546-47 (1972).

65. 426 U.S. 229 (1976).

66. Id. at 245.

67. See, e.g., Rogers v. Lodge, 458 U.S. 613, 621-22 (1982) (finding that the district court properly applied the intent test); City of Mobile v. Bolden, 446 U.S. 55, 66-68 (1980) (approving the intent test as discussed in Davis); Village of Arlington Heights v. Metropolitan Hous. Dev. Corp., 429 U.S. 252, 265 (1977) (upholding the intent test and noting that "the holding in Davis renffirmed a principle well established"). 
Effects are not, however, entirely irrelevant to an equal protection claim. Discriminatory effects are among a panoply of factors that are probative of a discriminatory state of mind. As the Court stated in Village of Arlington Heights v. Metropolitan Housing Development Corp. ${ }^{68}$ proof of discriminatory intent requires "a sensitive inquiry into such circumstantial and direct evidence of intent as may be available." ${ }^{69}$ In a more recent case, Rogers v. Lodge, ${ }^{70}$ which dealt with voting rights under the Fourteenth Amendment's Equal Protection Clause, the Supreme Court emphasized a point made in Davis: " 'discriminatory purpose may often be inferred from the totality of the relevant facts, including the fact, if it is true, that the law bears inore heavily on one race than another." "71

Although systematic disparate effects now constitute a relevant area of inquiry, the Supreme Court has not really lightened the plaintiff's arduous burden of reading the defendant's mind. Discriminatory intent is still rarely presumed from discriminatory effects. When, as is often the case in equal protection cases, the defendant is an institution of government, the plaintiff's burden will often be nearly impossible to satisfy. The Supreme Court itself, in Personnel Administrator v. Feeney, ${ }^{72}$ has indicated just how difficult the plaintiff's burden can be.

In Feeney, the Massachusetts legislature had passed a law granting military veterans absolute preference for state jobs. Because over ninetyeight percent of the veterans were males, ${ }^{73}$ the veteran's preference law had the foreseeable and natural effect of excluding females from state jobs. The law was challenged on equal protection grounds. Reversing the lower court, which found the law's adverse impact on women too inevitable to have been "unintended," the Supreme Court ruled that discriminatory purpose "implies more than intent as volition or intent as awareness of consequences. It imphes that the decisionmaker, in this case a state legislature, selected or reaffirmed a particular course of action at least in part 'because of,' not merely 'in spite of,' its adverse effects upon an identifiable group."74

Traditionalists most often defend the intent test by attacking its main alternative, the "effects test."75 Under the effects test, governmental liabil-

68. 429 U.S. 252 (1977).

69. Id. at 266.

70. 458 U.S. 613 (1982).

71. Id. at 618 (quoting Washington v. Davis, 426 U.S. 229, 242 (1976)). "Relevant facts" have included the magnitude of the disparity, prior discriminatory acts of the government revealing a deliberate pattern of conduct, and the foreseeability of the consequences of the government's actions. See, e.g., Dowdell v. City of Apopka, 698 F.2d 1181, 1186 (11th Cir. 1983).

72. 442 U.S. 256 (1979).

73. Id. at 270.

74. Id. at 279 (citation omitted).

75. See, e.g., Robert W. Bennett, "Mere" Rationality in Constitutional Law: Judicial Review and Democratic Theory, 67 CALIF. L. REv. 1049, 1076 (1979) (asserting that implementing the effects test would forbid so much legislation as to be "neither workable nor desirable"); Barry A. Miller, Comment, 
ity is based on the disproportionate impact of a law regardless of the intent behind the law. ${ }^{76}$ Hence, traditionalists argue, the strongest argument for the intent test may be that the effects test creates a standard that could have a chilling effect on legitimate governmental decisionmaking. ${ }^{77}$ In addition, traditionalists also argue that the effects test imports race-conscious decisionmaking into a constitutional provision that is intended to value race neutrality, ${ }^{78}$ imposes the cost of remedying a constitutional injury on "innocent" third parties (e.g., white males who had no hand in the legislative enactment), ${ }^{79}$ and forces the judiciary to make decisions that favor some legitimate social interests over others, ${ }^{80}$ a role that is constitutionally assigned to, and more competently performed by, the legislative branch of government.

Defenders of the intent test may also feel that legal responsibility, like moral responsibility, ought to rest not on what a person does but on what a person wills. In Feeney, the Supreme Court held that decisionmakers with a discriminatory purpose were legally responsible but excused those with mere knowledge of an imminent discriminatory effect. ${ }^{81}$ The Supreme Court and other civil rights traditionalists thus appear to be operating on the unstated assumption that legal and moral responsibility should be assessed under the same basic standards, at least in discrimination cases. Perhaps this is why the Court sometimes suggests that an "invidiously discriminatory animus" is required to satisfy the intent test. ${ }^{82}$

Proof of Racially Discriminatory Purpose Under the Equal Protection Clause: Washington v. Davis, Arlington Heights, Mt. Healthy, and Williamsburgh, 12 HARv. C.R.-C.L. L. Rev. 725, 738-39 (1977) (arguing that the effects test is inappropriate since it "would deeply involve the judiciary in political decisionmaking" and "would often [provide] a remedy disproportionate to the decisionmaker's wrongful act").

76. See Davis, 426 U.S. at $242-45$ (discussing various cases where courts found that discriminatory impact sufficed to show racial discrimination).

77. See, e.g., id. at 248 \& n.14; Paul Brest, The Supreme Court, 1975 Term-Foreword: In Defense of the Antidiscrimination Principle, 90 HARv. L. REv. 1, 11 (1976).

78. See John H. Ely, Legislative and Administrative Motivation in Constitutional Law, 79 Y ALE L.J. 1205, 1258-59 (1970) (applying this view in the context of criticizing jury sclection hased on proportional representation by race); John Kaplan, Segregation Litigation and the Schools-Part 11: The General Northem Problem, 58 Nw. U. L. Rev. 157, 188 (1963) (asserting this view as a basis for warning against the use of "benign" racial considerations in teacher selection and school segregation cases in general). But, from the perspective of minorities, the costs of a race-neutral interpretation of the Equal Protection Clause would appear to be far greater than the downside associated with the effccts test.

79. See, e.g., Hills v. Gautreaux, 425 U.S. 284, 293-94 (1976) (discussing the Milliken holding); Milliken v. Bradley, 418 U.S. 717, 744-47 (1974) (refusing to support a judicially-imposcd desegregation plan because it would have adverse effects on surrounding school districts which had not engaged in discrimination).

80. See Brest, supra note 77 , at $47-48$.

81. See supra text accompanying notes $72-74$.

82. See, e.g., Griffin v. Breckenridge, 403 U.S. 88, 102 (1971); Richardson v. Miller, 446 F.2d 1247, 1249 (3d Cir. 1971) (adopting the Griffin standard). 


\section{Reformists' Argument for the Effects Test}

Proceeding from the premise that FEO is conceptually sound but operationally flawed, ${ }^{83}$ reformists criticize rather than embrace the intent test. Although reformists espouse a formalized notion of racial equality, they do not believe that the intent test is the best way to implement FEO under the Equal Protection Clause.

Reformists begin by criticizing the assumption underlying the intent test that legal and moral responsibility should be treated alike under the Equal Protection Clause. ${ }^{84}$ In other words, reformists argue that legal responsibility should depend on the legal propriety of what a person does rather than on the moral propriety of what a person wills. In this vein, Oliver Wendell Holmes, in The Path of the Law, ${ }^{85}$ warned of the dangers "of confounding morality with law."86 Law and morality, Holmes explained, often yield very different interpretations of identical facts. For, while law seeks to regulate the behavior of the "bad" person (the person who cares only about material consequences), morality speaks to the "good" person, the person who "finds his reasons for conduct ... in the vaguer sanctions of conscience." ${ }^{\text {" }}$ Likewise, the argument continues, the "good," moral person does not need law to regulate her behavior; she will inevitably do what is legally right by following her conscience.

Based on this fundamental distinction between morality and law, reformists conclude that legal responsibility should depend on the effects of what a person does. As Holmes explained in the context of libel:

Three hundred years ago a parson preached a sermon and told a story out of Fox's Book of Martyrs of a man who had assisted at the torture of one of the saints, and afterward died, suffering compensatory inward torment. It happened that Fox was wrong. The man was alive and chanced to hear the sermon, and thereupon he sued the parson. Chief Justice Wray instructed the jury that the defendant was not liable, because the story was told innocently, without malice. He took malice in the moral sense, as importing a malevolent motive. But nowadays no one doubts that a man may be liable, without any malevolent motive at all, for false statements manifestly calculated to inflict temporal dainage. In stating the case in pleading, we still should call the defendant's conduct malicious; but, in my opinion at least, the word means nothing about motives, or even about the defendant's attitude toward the future, but only signifies

83. See supra text accompanying notes $40-43$.

84. See supra text accompanying notes 81-82.

85. Oliver W. Holmes, The Path of the Law, 10 Harv. L. Rev. 457 (1897).

86. Id. at 464 .

87. Id. at 459 . 
that the tendency of his conduct under the known circumstances was very plainly to cause the plaintiff temporal harm. ${ }^{88}$

The result in Feeney is clearly in conflict with this rationale. If legal responsibility turned on one's actions rather than on one's will, a finding of discriminatory motivation would be unnecessary. Knowledge of the discriminatory effect of one's actions would suffice to state an equal protection claim. To paraphrase Holmes' action-focused viewpoint, people would then be liable for the infliction of "temporal damage" irrespective of their intentions. Likewise, legislative bodies would be held legally responsible for the natural and foreseeable consequences of their actions. Accordingly, if a legislature proceeded with a particular course of action in spite of the negative impact it was likely to have on a protected class, the proper conclusion would be that the legislature acted illegally. ${ }^{89}$

In addition to assailing the intent test's confusion of legal and moral responsibility, reformists also criticize the traditionalists' standard on numerous other grounds. ${ }^{90}$ For example, Professor Karst argues that "the facts of racial inequality are the real problem."91 Where there are disproportionate effects, racial inequality exists regardless of governmental motivation; yet, focusing on governmental motivation causes courts and parties to ignore that inequality. ${ }^{92}$ This analysis suggests that the effects test is more effective than the intent test in enforcing the Equal Protection Clause.

Reformists have also argued that the intent test places an onerous burden on racial minorities, the very groups the Equal Protection Clause was designed to protect. The disadvantage arises from the fact that racial minority plaintiffs find it extremely difficult to prove that the defendant possessed the requisite discriminatory state of mind. ${ }^{93}$ This burden on the racial minority plaintiff is magnified when the defendant is a legislative body, as

88. Id. at 463 .

89. This is not an entirely unprecedented suggestion. As Professor Tonry has pointed out: "Although American constitutional law sometimes distinguishes between actions taken with the purpose of discriminating against blacks, and actions taken for other purposes but with knowledge that they will systematically disadvantage blacks, ... purpose and knowledge [should be treated] as moral equivalents (as they are in criminal law mens rea doctrines)." Michael Tonry, Racial Disproportion in US Prisons, 34 BrIT. J. CRIMINology 97, 112 (special issue 1994).

90. See, e.g., Brooks, supra note 5, at 84-87 (criticizing the intent test for imposing too heavy of a burden on plaintiffs); Theodore Eisenberg, Disproportionate Impact and Illicit Motive: Theories of Constitutional Adjudication, 52 N.Y.U. L. REv. 36, 47-50 (1977) (criticizing the intent test because courts will have difficulty finding a suspeet classification under its standards); Kenneth L. Karst, The Costs of Motive-Centered Inquiry, 15 SAN DiEgo L. Rev. 1163, 1165-66 (1978) (contending that the intent test places a heavy burden on plaintiffs and causes the parties to resort to name-calling, which takes the focus off racial inequality and ultimately harms relations between groups that will need to work with each other in the future).

91. Karst, supra note 90 , at 1165 (emphasis omitted).

92. Id.

93. Professor Ely notes that the effect of the intent test "has been in each case to deny the constitutional claim." John H. Ely, The Centrality and Limits of Motivation Analysis, 15 SAN Diego L. REv. 1155,1160 (1978); see also Karst, supra note 90, at 1165 (arguing that motive-centered doctrines "place[ ] a 'very beavy burden' of persuasion on the wrong side of the dispute" (footnote omitted)). 
is often the case with equal protection claims, and the plaintiff must prove a collectively discriminatory state of mind. ${ }^{94}$

Justice Stevens, a reformist Justice on an otherwise traditionalist Supreme Court, has criticized the Court's adoption of the intent test for this very reason, observing that:

[I]n the long run constitutional adjudication that is premised on a case-by-case appraisal of the subjective intent of local decisionmakers cannot possibly satisfy the requirement of impartial administration of the law that is embodied in the Equal Protection Clause....

The costs and the doubts associated with litigating questions of motive, which are often significant in routine trials, will be especially so in cases involving the "motives" of legislative bodies. ${ }^{95}$

Justice Stevens further faults the intent test: "It is incongruous that subjective intent is identified as the constitutional standard and yet the persons who allegedly harbored an improper intent are never identified or mentioned." 96

Finally, perhaps the reformists' strongest logical argument in support of the effects test is that it has been employed as an acceptable standard of liability in many statutory contexts involving civil rights. ${ }^{97}$ If the effects test is as flawed as traditionalists claim, why is it used at all? Nothing is intrinsically wrong with the effects test, and nothing is intrinsically right about the intent test. The selection of one test over the other is simply a matter of perspective, namely, how one approaches civil rights at the most fundamental level..$^{98}$

Clearly, the reformists' civil rights perspective produces an analysis of the intent test that is very different from that of the traditionalists. Most significantly, traditionalists, believing that FEO has been properly implemented, support the intent test, while reformists do not. Reformists are,

94. For a discussion of how institutional motivation may be proven, see Larry G. Simon, Racially Prejudiced Governmental Actions: A Motivation Theory of the Constitutional Ban Against Racial Discrimination, 15 SAN DrEGo L. Rev. 1041, 1097-107 (1978).

95. Rogers v. Lodge, 458 U.S. 613, 643, 645 (1982) (Stevens, J., dissenting).

96. Id. at 647 (Stevens, J., dissenting).

97. For example, in Griggs v. Duke Power Co., 401 U.S. 424 (1971), the Court applied the effects test in the context of employment discrimination under Title VII of the Civil Rights Act of 1964 and struck down an employer's use of an intelligence test for hiring purposes because the test was unrelated to job performance. In so holding, the Court noted that "Congress directed the thrust of the Act to the consequences of employment practices, not simply the motivation." Id. at 432. In 1991, Congress, for the first time, expressly embraced the effects test within the text of Title VII. See 42 U.S.C. $\$ 2000 \mathrm{e}$ 2(k) (Supp. IV 1992). Other statutes in which the effects test is deemed to be an acceptable standard of liability include the Age Discrimination in Employment Act (ADEA), 29 U.S.C. §§ 621-634 (1988 \& Supp. IV 1992), and the Voting Rights Act of 1965, 42 U.S.C. $\$ \S 1971,1973$ to 1973 ff-6 (1988 \& Supp. IV 1992).

98. See, e.g., supra text accompanying notes $51-52$ (discussing CRT's claim that classical-liberals are insensitive to minorities' "outsider" perspective). 
therefore, more inclined to engage in social engineering to achieve racial justice. To a large extent, they are willing to make the necessary trade-offs, such as adopting the effects test, to bring about measurable racial symmetry. ${ }^{99}$

Although traditionalists are also concerned about lingering racial inequality, they seem unwilling to make the necessary trade-offs that can lead to greater legal or social symmetry between the races. In other words, they give less deference than reformists to the interests of racial minorities.

Likewise, reformists, who accept FEO in principle, would be expected to be less likely than race crits to endorse extensive sociolegal trade-offs that favor people of color. We shall take a closer look at this proposition next as we discuss the race crits' analysis of the intent test.

\section{CRT's "Culturally Informed" Intent Test}

Race crits, in rejecting FEO, ${ }^{100}$ also reject the traditionalists' intent test. Professor Charles Lawrence, a prominent race crit, provides a powerful analysis of the intent test from a CRT perspective. In a highly regarded article, Professor Lawrence states:

Much of one's inability to know racial discrimination when one sees it results from a failure to recognize that racism is both a crime and a disease. This failure is compounded by a reluctance to admit that the illness of racism infects almost everyone. Acknowledging and understanding the malignancy are prerequisites to the discovery of an appropriate cure. But the diagnosis is difficult, because our own contamination with the very illness for which a cure is sought impairs our comprehension of the disorder.

Americans share a common historical and cultural heritage in which racism has played and still plays a dominant role. Because of this shared experience, we also inevitably share many ideas, attitudes, and beliefs that attach significance to an individual's race and induce negative feelings and opinions about nonwhites. To the extent that this cultural belief system has influenced all of us, we are all racists. At the same time, most of us are unaware of our racism. We do not recognize the ways in which our cultural experience has influenced our beliefs about race or the occasions on which those beliefs affect our actions. In other words, a large part of the behavior that produces racial discrimination is influenced by unconscious racial motivation.

There are two explanations for the unconscious nature of our racially discriminatory beliefs and ideas. First, Freudian theory

99. See Brooks, supra note 5, at 158 (discussing adoption of the effects test "on an equal footing[ ] with the intent test" in the context of remedying discriminatory housing policy).

100. See supra Part II.A. 
states that the human mind defends itself against the discomfort of guilt by denying or refusing to recognize those ideas, wishes, and beliefs that conflict with what the individual has learned is good or right. While our historical experience has made racism an integral part of our culture, our society has more recently embraced an ideal that rejects racism as immoral. When an individual experiences conflict between racist ideas and the societal ethic that condemns those ideas, the mind excludes his racism from consciousness.

Second, the theory of cognitive psychology states that the culture-including, for example, the media and an individual's parents, peers, and authority figures-transmits certain beliefs and preferences. Because these beliefs are so much a part of the culture, they are not experienced as exphicit lessons. Instead, they seem part of the individual's rational ordering of her perceptions of the world. The individual is unaware, for example, that the ubiquitous presence of a cultural stereotype has influenced her perception that blacks are lazy or unintelligent. Because racism is so deeply ingrained in our culture, it is likely to be transmitted by tacit understandings: even if a child is not told that blacks are inferior, he learns that lesson by observing the behavior of others. These tacit understandings, because they have never been articulated, are less likely to be experienced at a conscious level.

In short, requiring proof of conscious or intentional motivation as a prerequisite to constitutional recognition that a decision is racedependent ignores much of what we understand about how the human mind works. It also disregards both the irrationality of racism and the profound effect that the history of American race relations has had on the individual and collective unconscious.

... [T]he "cultural meaning" of an allegedly racially discriminatory act is the best available analogue for, and evidence of, a collective unconscious that we cannot observe directly. This test would thus evaluate governmental conduct to determine whether it conveys a symbolic message to which the culture attaches racial significance. A finding that the culture thinks of an allegedly discriminatory governmental action in racial terms would also constitute a finding regarding the beliefs and motivations of the governmental actors: the actors are themselves part of the culture and presuniably could not have acted without being influenced by racial considerations, even if they are unaware of their racist beliefs. ${ }^{101}$

This analysis is unique in both its deconstruction and reconstruction of the intent test. At the deconstruction end, it challenges the ability of the

101. Lawrence, supra note 3, at 321-24 (footnotes omitted). 
intent test to uncover "procedural" racism ${ }^{102}$ and questions the effectiveness of the Equal Protection Clause in redressing racial injustice in our society. Professor Lawrence suggests that the traditionalists' version of the intent test is too detached from American society's subconscious culture of racism and too divorced from the life experiences of the primary beneficiaries of equal protection law. As a result, the traditional formulation of the intent test erroneously treats racism as an anomaly rather than as normal science.

By placing his analysis within the context of our racist culture and applying the teachings of social science as well as the life experiences of racial minorities, Professor Lawrence adds a richness and realisin to the discussion of the intent test that is lacking in classical-liberal scholarship. One gains a deeper understanding of the intent test, especially its limitations, when the effects of subconscious racism are exposed. One also comes to appreciate the complexity of the social problem that the intent test seeks to redress.

Professor Lawrence's reconstruction of the intent test builds effectively on insights gleaned from his deconstruction of the test. The specific legal reform he proposes, a "culturally informed" intent test, is connected to the life experiences and needs of the outsider class. Although arguably not as transformative as the effects test, which is triggered by the mere existence of a disparate impact, ${ }^{103}$ Professor Lawrence's modified intent test is still more effective than the traditional intent test in bringing about racial justice. However, it cannot be denied that although reformists believe in the traditional goal of FEO, they may be willing to go as far as, or even farther than, race crits in making sociolegal trade-offs that favor racial minorities. ${ }^{104}$

\section{B. The Standard of Judicial Review}

\section{Traditionalists' Argument for the Strict Scrutiny Test}

Like the standard of liability, the standard of judicial review for racial classifications in equal protection law is not prescribed in the text of the Constitution or in its legislative history. The Supreme Court has had to invent such a standard. Taking a traditionalist approach, the Court has cre-

102. "Procedural" racism is discussed supra text accompanying notes $48-49$.

103. See supra text accompanying notes 75-76. As we have learned from Title VIl litigation, proof of disparate effects is much easier to establish than proof of disparate treatment. This is because the burden of persuasion as to the defendant's state of mind is on the plaintiff in disparate treatment litigation, even when the defendant lies about the reason for its actions toward the plaintiff. See Saint Mary's Honor Ctr. v. Hicks, 113 S. Ct. 2742, 2746-48 (1993). State of mind is not a relevant consideration in disparate impact litigation, however. See International Bhd. of Teamsters v. Unitcd States, 431 U.S. 324, 336 n.15 (1977).

104. While Professor Lawrence clearly favors a new version of the intent test, there is nothing in his article to suggest that he disfavors the effects test. Indeed, his deconstruction of the intent test is equally applicable to a defense of the effects test. See Lawrence, supra note 3, at 321. 
ated the "strict scrutiny test" as the primary standard of judicial review for racial classifications.

Designed to implement FEO's policy of colorblindness, ${ }^{105}$ the strict scrutiny test facilitates close judicial review of "suspicious" legislative enactments. 106 Specifically, the test "operates to strike down, as a denial of equal protection of the laws, any governmental activity or legislation that either is predicated on an explicit racial or other 'suspect classification' or violates a 'fundamental personal interest." "107

Surviving strict scrutiny is like climbing Mount Kilimanjaro two times. The Supreme Court has fashioned a two-prong standard for applying the strict scrutiny test that is fatal to most acts of government brought under its review. As one scholar has explained: "An act under scrutiny is saved from judicial strangulation only if the government can meet a twofold burden. First, the classification must be justified by a 'compelling governmental interest.' Second, the means chosen to achieve the classification's purpose must be the least restrictive, most narrowly tailored means available."108

While there is disagreenuent among traditionahists as to whether state or local governments' use of racial classifications to remedy the effects of past individual discrimination serves a "compelling governmental interest" or is otherwise justified, ${ }^{109}$ there is one critical point on which most tradi-

105. See supra text accompanying note 36 .

106. For cases applying the strict scrutiny test to claims based on the Equal Protection Clause of the Fourteenth Amendment, see, e.g., City of Richmond v. J.A. Croson Co., 488 U.S. 469, 493-94 (1989); United States v. Paradise, 480 U.S. 149, $166 \&$ n.17 (1987). For an example applying the test to a claim based on the equal protection component of the Fifth Amendment's Due Process Clause, see Local 28 of the Sheet Metal Workers' Int'l Ass'n v. EEOC, 478 U.S. 421, 479-80 (1986).

107. Brooks, supra note 5, at 52. Race is a suspect classification. See, e.g., McDonald v. Board of Election Comm'rs, 394 U.S. 802, 807 (1969); Bolling v. Sharpe, 347 U.S. 497, 499 (1954); see also Polyvios G. Polyviou, The EQual Protection of the Laws 238-40, 311 -14 (1980) (characterizing race as a suspect classification deserving of strict scrutiny); Developments in the Law-Equal Protection, 82 HARv. L. Rev. 1065, 1087-91 (1969) (characterizing race as a suspect classification and discussing the Court's rejection of the "colorblind" interpretation of the Equal Protection Clause). Courts often find invidious discrimination present when fundamental personal interests are violated. See Reynolds v. Sims, 377 U.S. 533, 561 (1964). Fundamental personal interests include the right to procreate, Skinner v. Oklahoma, 316 U.S. 535, 541 (1942), the right to vote, Reynolds, 377 U.S. at 56162, and the right to engage in interstate travel, Shapiro v. Thompson, 394 U.S. 618, 629-31 (1969), overruled on other grounds by Edelman v. Jordan, 415 U.S. 651 (1974).

108. Brooks, supra note 5, at 52; see also Wygant v. Jackson Bd. of Educ., 476 U.S. 267, 273-74 (1986) (plurality opinion) (discussing this test); Palmore v. Sidoti, 466 U.S. 429, $432-33$ (1984) (same).

109. In his Croson concurrence, Croson, 488 U.S. at 520-24 (Scalia, J., concurring in the judgment), Justice Scalia takes issue with the suggestion in Justice O'Connor's majority opinion that states can use racial classifications "to ameliorate the effects of past discrimination," id. at 476-77. Justice Scalia acknowledges that the Court in Fullilove v. Klutznick, 448 U.S. 448 (1980), "upheld legislative action by Congress similar in its asserted purpose to that at issue [in Croson]," Croson, 488 U.S. at 521 (Scalia, J., concurring in the judgment), and that in United States v. Paradise, 480 U.S. 149 (1987), and Local 28 of the Shect Metal Workers' Int'1 Ass'n v. EEOC, 478 U.S. 421 (1986), the Court "permitted [lower] federal courts to prescribe quite severe, race-conscious remedies [i.e., quotas] when confronted with egregious and persistent unlawful discrimination," Croson, 488 U.S. at 521 (Scalia, J., concurring in the judgment). But Justice Scalia would not extend those holdings to the states. He 
tionalists agree, namely, that "the level of Fourteenth Amendment "scrutiny does not change merely because the challenged classification operates against a group that historically has not been subject to governmental discrimination." "110 Thus, traditionahists believe that the strict scrutiny test should apply to all racial classifications, whether invidious, as in the days of Jim Crow, ${ }^{111}$ or benign, as in the case of affirmative action programs. Both invidious and benign racial classifications are thereby put at equal risk. ${ }^{112}$

The traditionalists' justification for applying the strict scrutiny test to benign racial classifications (hereinafter referred to as "affirmative action") $)^{113}$ has less to do with a close reading of the Fourteenth Amendment ${ }^{114}$ than with their fundamental perspective on civil rights. In

argues that "it is one thing to permit racially based conduct by the Federal Government-whose legislative powers concerning matters of race were explicitly enhanced by the Fourtcenth Amendmentand quite another to permit it by the precise entities against whose conduct in matters of race that Amendment was specifically directed ...."Id. at 521-22 (Scalia, J., concurring in the judgment) (citations omitted).

110. United States v. Paradise, 480 U.S. 149, 196 (1987) (O'Connor, J., dissenting) (quoting Wygant v. Jackson Bd. of Educ., 476 U.S. 267, 273 (1986)).

111. See supra text accompanying notes 20-35.

112. The strict scrutiny test has been described as " 'strict' in theory and fatal in fact." Gerald Gunther, The Supreme Court, 1971 Term-Foreword: In Search of Evolving Doctrine on a Changing Court: A Model for a Newer Equal Protection, 86 HARv. L. Rev. 1, 8 (1972).

113. The federal government defines affirmative action in the employment context as "actions appropriate to overcome the effects of past or present practices, polieies, or other barriers to equal employment opportunity." 29 C.F.R. § 1608.1(c) (1993). This definition would include benign racial classifications. For a discussion of benign racial classifications and types of "voluntary" and "involuntary" affimuative action programs, including "quotas" and "goals," see Roy L. Brooks, The Affirmative Action Issue: Law, Policy, and Morality, 22 ConN. L. REv. 323, 334-48 (1990).

114. The central constitutional question presented in affimative action is whether the original intent of the Equal Protection Clause-"No state shall ... deny to any person within its jurisdiction the equal protection of the laws," U.S. CoNST. amend. XIV, § 1-permits the states or their political subdivisions to establish racial preferences in favor of minorities or gender preferences in favor of women. Unfortunately, there is no clear answer to this question. As historian Eric Foncr states:

For more than a century, politicians, judges, lawyers, and scholars have debated the meaning of this elusive language. The problem of establishing the Amendment's "original intent" is complicated by the fact that its final wording resulted from a series of extremely narrow votcs in the Joint Committee and subsequent alteration on the floor of Congress. To complicate matters further, the broadest statements of the Amendment's purposes originated with opponents, who, in an attempt to discredit the measure, claimed it would destroy the powers of the states, establish equality "in every respect" between black and white, and cmpowcr Congress to legislate on any local matter it chose-an interpretation Republicans vehemently denied.

Whether the courts should be bound by the "original intent" of a constitutional amendment is a political, not an historical question. But the aims of the Fourtcenth Amendment can only be understood within the political and ideological context of 1866: the break with the President, the need to find a measure upon which all Republicans could unite, and the growing consensus within the party around the need for strong federal action to protect the freedmen's rights, short of the suffrage. Despite the many drafts, changes, and deletions, the Amendment's central principle remained constant: a national guarantee of equality before the law.

ERIC FONER, RECONSTRUCTION: AMERICA's UNFINISHED REVOlution, 1863-1877, at 256.57 (1988).

Taking a broader view of congressional activity during Reconstruction may add insight to the constitutional question. The Thirty-Ninth Congress not only proposed the 14th Amendment, but also, in the same year, enacted both the Civil Rights Act of 1866 and the race-conscious law, the Freedmen's 
other words, traditionalists believe that the Equal Protection Clause should vindicate the colorblind principle of FEO. ${ }^{115}$ Justice Stewart, quoting from the dissenting opinion in Plessy, stated: "Our Constitution is color-blind, and neither knows nor tolerates classes among citizens.... The law regards man as man, and takes no account of his surroundings or his color. . ." "116 Not surprisingly, Justice Stewart viewed all racial classifications as invidious. ${ }^{117}$ Justice Scalia has provided an inipassioned defense of the colorblind principle in the context of affirmative action:

The difficulty of overcoming the effects of past discrimination is as nothing conipared with the difficulty of eradicating from our society the source of those effects, which is the tendency-fatal to a Nation such as ours - to classify and judge men and women on the basis of their country of origin or the color of their skin. A solution to the first problem that aggravates the second is no solution at all. I share the view expressed by Alexander Bickel that "[t]he lesson of the great decisions of the Supreme Court and the lesson of contemporary history have been the same for at least a generation: discrimination on the basis of race is illegal, immoral, unconstitutional, inherently wrong, and destructive of democratic society."118

Reformists give a different read to the Equal Protection Clause. Like traditionalists, however, their construction of the Clause has less to do with constitutional text than with their civil rights perspective.

Bureau Act of 1866. The latter Act mandated that newly-freed slaves be given food, clothing, legal assistance, special schools, and other services to help them in their transition to a new way of life in America. Professor Schnapper explains the significance of this legislative activity:

The composition of the majority supporting the amendment was nearly identical to that which supported the Act. ...

... [T] complementary, and opponents viewed the two, together with the Civil Rights Act of 1866, as part of a single coherent policy. No member of Congress hinted at any inconsistency between the fourteenth amendment and the Freedmen's Bureau Act.

Eric Schnapper, Affirmative Action and the Legislative History of the Fourteenth Amendment, 71 VA. L. Rev. 753, 784-85 (1985) (footnotes omitted). Does the Thirty-Ninth Congress' legislative activity only support congressionally designed affirmative action programs for direct victims of invidious discrimination? The Supreme Court continues to grapple with the permissibility of affirmative action programs, even those created by Congress. See, e.g., Metro Broadcasting, Inc. v. FCC, 497 U.S. 547 (1990) (upholding, by a 5-4 margin, an FCC policy that gave preference to minority ownership of broadcast licenses and facilities). For further discussion of the Freedmen's Bureau Act, see Encyclopedia of Black America 72-77 (W. Augustus Low \& Virgil A. Clift eds., Da Capo Press 1990) (1981).

115. See supra text accompanying note 36 .

116. Fullilove v. Klutznick, 448 U.S. 448, 522-23 (1980) (Stewart, J., dissenting) (quoting Plessy v. Ferguson, 163 U.S. 537, 559 (1896) (Harlan, J., dissenting), overruled by Brown v. Board of Educ., 347 U.S. 483 (1954)) (alteration in original).

117. Id. at 526 .

118. City of Richmond v. J.A. Croson, Co., 488 U.S. 469, 520-21 (1989) (Scalia, J., concurring in the judgment) (quoting Alexander Bickel, The Morality of Consent 133 (1975)). 


\section{Reformists' Argument for an Intermediate Scrutiny Test}

While the reformists agree with the notion that equal protection law should seek to vindicate FEO, they disagree with the traditionalists' way of implementing that concept. Reformists argue that the use of the strict scrutiny test to effectuate FEO in the affirmative action context demonstrates poor judgment because the test invokes FEO's colorblind tenet at the wrong time. That is, "[e]xcept in a very limited situation, [the test] enjoins the public sector's use of race-conscious ... policies or practices that would promote racial inclusion. In so doing, it treats policies and practices that result in racial exclusion pari passu (on an equal footing) with those that are socially beneficial."119 In short, reformists contend that the strict scrutiny test should apply only to invidious racial classifications, not to benign ones.

Another argument advanced by reformists relates to a primary objective of the Equal Protection Clause. One of the principal purposes of the Equal Protection Clause is to protect "discrete and insular minorities" from majoritarian prejudice or indifference. ${ }^{120}$ Whereas, in the affirmative action context, where the white majority places the burden not upon minorities but upon itself, a less demanding level of judicial scrutiny is acceptable, reformists argue.

Accordingly, most reformists advocate the use of an intermediate standard of judicial review for affirmative action. An intermediate scrutiny test lies somewhere between the strict scrutiny test described above and the "rational basis" test, which provides the widest degree of judicial deference and applies to legislative enactinents that do not involve suspect classifications (such as race) or implicate fundamental rights. ${ }^{121}$

Several versions of an intermediate scrutiny test, most with a twoprong, ends-means component, have been articulated over the years. Justices Marshall, Brennan, White, and Blackmun, for example, have advocated an intermediate scrutiny test that would uphold racial classifications, including affirmative action, that serve "important governmental objectives," such as the desire to redress past societal discrimination, and are

119. Brooks, supra note 5 , at 53 .

120. See United States v. Carolene Products Co., 304 U.S. 144, 153 n.4 (1938). For an argument that the scope and significance of footnote 4 in Carolene Products are overstated, see Daniel A. Farber \& Philip P. Frickey, Is Carolene Products Dead? Reflections on Affirmative Action and the Dynamics of Civil Rights Legislation, 79 CALIF. L. REv. 685 (1991).

121. See, e.g., McDonald v. Board of Election Comm'rs, 394 U.S. 802, 809 (1969) ('Legislatures are presunied to have acted constitutionally ..., and their statutory classifications will be set aside only if no grounds can be conceived to justify then."). In this case, the Supreme Court held that a classification based on handicapped status was not suspect, and thus, the Court applied the rational basis test. The Court ultimately upheld the constitutionality of the classification under the Equal Protection Clause. 
"substantially related to achievement of those objectives."122 Justice Stevens, however, would uphold a racial classification if it vindicates a public interest and if the means employed to effectuate that interest justify the resulting adverse effects on the disadvantaged group, which, in the case of affirmative action, usually means white males. ${ }^{123}$ Another intermediate scrutiny test would uphold a racial classification if it were "designed to promote racial inclusion and [did] not 'unnecessarily trammel the interests' of the group disadvantaged by the racial classification."124

Notwithstanding the variety of intermediate scrutiny tests, the Supreme Court has used only the Marshall test. Moreover, the Court has not applied that test to a state or local affirmative action program for minorities. Rather, the Court has only applied the test to racial classifications created by the federal government ${ }^{125}$ and to gender classifications made at all levels of government. ${ }^{126}$

The major difference between most of the intermediate scrutiny tests and the strict scrutiny test is that while the desire to redress past societal discrimination would be an "important governmental objective" or compensatory purpose ${ }^{127}$ under an intermediate scrutiny standard, it is not considered a "compelling governmental interest"128 sufficient to satisfy strict scrutiny. Justice $O^{\prime}$ Connor has argued that the past societal discrimination argument embodies "a generalized assertion that there has been past discrimination in an entire industry [and] provides no guidance for a legislative body to determine the precise scope of the injury it seeks to remedy. It 'has no logical stopping point.' "129 But why, reformists wonder, is there a

122. Wygant v. Jackson Bd. of Educ., 476 U.S. 267, 301-02 (1986) (Marshall, J., dissenting) (quoting Regents of the Univ. of Cal. v. Bakke, 438 U.S. 265, 359 (1978) (Brennan, White, Marshall, and Blackmun, JJ., concurring in the judgment in part and dissenting in part)).

123. Id. at 313 (Stevens, J., dissenting).

124. Brooks, supra note 5, at 163. This test is already employed in the Title VII context. See id.

125. See Metro Broadcasting, Inc. v. FCC, 497 U.S. 547 (1990) (upholding the classification by a 5-4 vote).

126. The Court has applied Justice Marshall's test to gender-based classifications that disfavor women, see, e.g., Frontiero v. Richardson, 411 U.S. 677, 691-92 (1973) (Powell, J., concurring in the judgment) (plurality opirion) (relying on Reed to hold that a federal statute providing servicemen but not servicewomen a dependency allowance for spouses violated the Fifth Amendment); Reed v. Reed, 404 U.S. 71 (1971) (striking down a state statute that established a preference for male estate admimistrators), and to gender-based classifications that create preferences for women, see, e.g., Mississippi Umiv. for Women v. Hogan, 458 U.S. 718 (1982) (invalidating a female-only admissions policy on the ground that its purpose was not to compensate for past discrimination against women); Craig v. Boren, 429 U.S. 190 (1976) (invalidating a state law that prohibited the sale of 3.2 beers to males between the ages of 18 and 20 but that allowed such sales to women in the same age bracket); Califano v. Webster, 430 U.S. 313 (1977) (upholding a social security formula used to calculate retirement benefits that yielded greater retirement income for women than for men).

127. See cases cited supra note 126, particularly Hogan.

128. See City of Richmond v. J.A. Croson, Co., 488 U.S. 469, 496-97 (1989) (reiterating the Court's view that, by itself, an aim of remedying societal discrimination does not satisfy the "compelling governmental interest" prong).

129. Id. at 498 (quoting Wygant v. Jackson Bd. of Educ., 476 U.S. 267, 275 (1986) (plurality opinion)). 
"logical stopping point" for past societal discrimination under an intermediate scrutiny test but not under a strict scrutiny test?

Establishing past societal discrimination is much easier than proving past discrimination by a particular institution. To this extent, it is easier to succeed under an intermediate scrutiny test than under the strict scrutiny test. This means that in the context of state-created affirmative action, "[f]emales and minorities ... receive unequal treatment under the equal protection clause, with females enjoying better treatment than black Americans, the intended primary beneficiary group of the equal protection clause." 130

The fundamental difference between the traditionalists' and reformists' perspectives on the application of the strict scrutiny test to affirmative action can be understood as a disagreement over the degree of emphasis to be given to FEO's twin policies, colorblindness and racial integration. ${ }^{131}$ In the context of affirmative action, traditionalists seem willing to promote colorblindness at some expense to racial integration, while reformists seem inclined to advance racial integration at some cost to colorblindness.

Some reformists argue that the best logical and sociological resolution of FEO's internal conflict, the tension between the colorblind and racial integration policies, is to defer to FEO's social goal-the attainment of a racially symmetrical society, one in which racial minorities are brought into the mainstream, including its power centers. ${ }^{132}$ Colorblindness and racial integration are simply two vehicles available in our society for bringing America closer to a racially symmetrical society. Reformists argue that colorblindness, through the operation of the strict scrutiny test, is the best way to bring about a racially symmetrical society in the context of Jim Crow legislation, where racial classifications are intended to exclude racial minorities from mainstream society. On the other hand, they argue that the racial integration policy moves America closer to a racially symmetrical society than the colorblind policy, where, in the context of affirmative action, racial classifications are intended to be racially inclusive. The colorblind policy only impedes racial progress in the affirmative action context. Furthermore, given the limited scope of affirmative action, ${ }^{133}$ placing greater emphasis on the racial integration policy does little harm to the interests of white males as a group. Thus, because an intermediate scrutiny test gives greater deference to the integration policy than the strict scrutiny test, intermediate scrutiny provides a better implementation of FEO in the affirmative action context.

130. Brooks, supra note 113 , at 350 .

131. See supra text accompanying note 36 .

132. See supra text accompanying note 35 .

133. See Brooks, supra note 113, at 353-54 (arguing that the "scope and operation" of affirmative action are so limited that affirmative action "has not and will not alter the nation's power structure"). 
The differences between the traditionalist and reformist approaches to the standard of review for racial classifications in equal protection law are quite apparent. We now consider the CRT approach.

\section{CRT's Complex Argument}

Race crits have yet to provide an in-depth analysis of the standard of review for affirmative action cases. There is, however, plenty of critical analysis concerning affirmative action generally. Drawing upon this discussion, we shall speculate about the CRT reconstructive position on the standard of review issue. Our focus continues to be on the standard of review and not on the overall merits of affirmative action. We shall consider aspects of that more general debate only insofar as it is necessary to "invent" the CRT proposal for the affirmative action standard of review.

Much of the CRT scholarship on affirmative action has been collected in Professor Daniel Farber's article in this Symposium. ${ }^{134}$ Professor Farber correctly observes that CRT scholars "hold differing views about affirmative action."135 For example, while Professors Patricia Williams and Robin Barnes exhibit unmistakable support for affirmation action, ${ }^{136}$ Professors Derrick Bell and Richard Delgado display varying degrees of ambivalence toward the issue. ${ }^{137}$

We begin with Professors Williams and Barnes. As Professor Farber points out, both Wilhams and Barnes offer similar arguments in support of affirmative action. Wilhams argues that affirmative action "is a recognition of [black] individuality that re-places blacks as a social statistic . . . It is an act of verification and of vision."138 Barnes argues that affirmative action is needed "not only to remedy past discrimination and abate the effects of today's exclusionary practices, but also to stem the tide of perpet-

134. Daniel A. Farber, The Outmoded Debate over Affirmative Action, 82 CALIF. L. Rev. 893 (1994).

135. Id. at 905 .

136. Id. at 905-06.

137. Id. at 906-07. It is important to note at the outset that it would be very wrong to take Bell and Delgado's reservations about affirmation action as an indication of their lack of support for minority hiring. Nor would it be fair to criticize them as two middle-class minorities who, in mid-life, have reached a state of luxurious despair or intellectual paralysis over affirmative action. Both are widely recognized among minority professors for their longstanding support for minority hiring. Bell has even sacrificed an endowed chair at Harvard Law School to fight for minority hiring. See supra note 52. Hence, we believe their criticism of affirmative action has little to do with benign racial classifications. Indeed, such classifications are implicit in the empowerment concept. See supra text accompanying note 59. Instead, they are more critical of the way liberal institutions and reformists typically apply affirmative action. Thus, we analogize Bell and Delgado's view of affirmative action to the reformists' approach to FEO: they like the concept but dislike the manner in which it has been applied.

138. Williams, supra note 3, at 50; see also Farber, supra note 134, at 905-06 (quoting this passage). 
ual domination that has been the prerogative of the 'normal' white male for all too long." 139

Based on these statements, we are certain of one thing: Williams and Barnes would not embrace the strict scrutiny test as a standard of review for affirmative action. This test does little to advance empowerment, the CRT concept of racial equality. ${ }^{140}$ Beyond the strong sense that they would reject the strict scrutiny test, we are not sure where they would come out on the standard of review question. On the one hand, they might adopt an intermediate scrutiny test ${ }^{141}$ because their arguments are indistinguishable from the arguments some reformists offer in support of affirmative action. ${ }^{142}$ In this case, they have nothing new to say about the standard of review for affirmative action. On the other hand, they might view the rational basis test ${ }^{143}$ as the appropriate standard of review for affirmative action. Providing the greatest judicial deference to state decisions, the rational basis test would be the most empowering and socially transformative of the standards of review. For that reason, we believe that Professors Williams and Barnes would support the rational basis test for affirmative action. This reconstructive measure is certainly different from what the classical-liberal perspectives bring to the table.

Neither Professors Bell nor Delgado support the manner in which liberal institutions have applied affirmative action. They believe that affirmative action, as applied by law schools and other liberal institutions, has done more good for whites than for minorities. Bell argues that affirmative action, as typically applied, allows so few minorities to "make it" that, in reality, it maintains the status quo while pacifying minorities. But, seeing no real alternative for fighting eternal racism, Bell concludes that "[f]or now," affirmative action "must be defended." 144

Given that Professor Bell wishes affirmative action had more transformative power, he, like Professors Williams and Barnes, would probably prefer the standard of review that packs the most minority punch-the rational basis test. But for Bell there may be another choice as well. His belief in "racial realism"145 gives him the option of simply not playing the legal analysis "game" anymore. Indeed, most recently, he has advocated

139. Robin D. Barnes, Politics and Passion: Theoretically a Dangerous Liaison, 101 YALE L.J. 1631, 1649 (1992) (book review); see also Farber, supra note 134, at 906 (quoting this passage).

140. See supra text accompanying note 59.

141. See supra text accompanying notes 121-24.

142. For example, Justice Blackmun, who usually takes a reformist approach to civil rights, has argued: "In order to get beyond racism, we must first take account of race. There is no other way. And in order to treat some persons equally, we must treat them differently. We cannot-we dare not-let the Equal Protection Clause perpetuate racial supremacy." Regents of the Univ. of Cal. v. Bakke, 438 U.S. 265, 407 (1978) (Blackmun, J.).

143. See supra text accompanying note 121 .

144. Derrick A. Bell, Jr., Bakke, Minority Admissions, and the Usual Price of Racial Remedies, 67 Calif. L. Rev. 3, 19 (1979); see also Farber, supra note 134, at 907 (quoting this passage).

145. See supra note 56 . 
opting out of the game in favor of what he considers to be the most minority-empowering and natural device possible: simply allow whites to indulge their taste for discrimination but require them to pay a price to the government to aid minorities. ${ }^{146}$ In this way, whites can maximize personal utility, and minorities are guaranteed concrete benefits. ${ }^{147}$

Like Professor Bell, Professor Delgado also believes that the typical application of affirmative action ultimately serves whites' self-interests because it keeps the number of minorities hired and promoted at levels small enough for whites to accept. As Delgado states, affirmative action ensures that "[n]ot too many [minorities will be selected], for that would be terrifying, nor too few, for that would be destabilizing." 148

Delgado argues that even the beneficiaries of affirmative action are devalued by the reformists' application of affirmative action. The value of a minority student who is brought in under a "diversity program" is measured in terms of her capacity to enricl the educational experiences of whites. She is presented "as an ornament, a curiosity, one who brings an element of the piquant to the lives of white professors and students." 149 And minority professors, not whites, are called upon to assume the stressful position of "role model." "Being a role model is a tough job, with long hours and much heavy lifting," Professor Delgado explains. 150 "You are expected to uplift your entire people."151

Although Professor Delgado appears to reject reformist affirmative action outright as "something no self-respecting attorney of color ought to support," 152 he has suggested in a subsequent writing that such affirmative

146. See infra Part IV.C. for a discussion of Professor Bell's proposal, "The Racial Preference Licensing Act."

147. The question, of course, is whether there are any externalities associated with Professor Bell's proposal. For example, will minorities be fully compensated for the harms to dignity that might result from such legalized discrimination?

148. Richard Delgado, Affirmative Action as a Majoritarian Device: Or, Do You Really Want To Be A Role Model?, 89 Mich. L. Rev. 1222, 1224 (1991); see also Farber, supra note 134, at 907 n.96 (quoting this passage).

149. Delgado, The Imperial Scholar, supra note 3, at 570 n.46; see also Farber, supra note 134, at 907-08 (quoting this passage). But reformists would suggest that minorities should care less about what whites think about them and more about taking advantage of every scarce opportunity that comes along. See Roy L. Brooks, Once the Door Is Open, Wash. Post, Sept. 8, 1991, Book World, at 4 (reviewing Stephen L. Carter, Reflections of an Affirmative Action Baby (1991) and suggesting that commentators such as Professor Carter should worry less about whites' suspicions of affirmative action and pay more attention to the considerable accomplishments of affirmative action beneficiaries).

150. Delgado, supra note 148, at 1226; see also Farber, supra note 134, at 908 (quoting this passage); Roy L. Brooks, Life After Tenure: Can Minority Law Professors Avoid the Clyde Ferguson Syndrome?, 20 U.S.F. L. REv. 419 (1986) (cataloguing the special burdens of tenured minority law professors). Professor Delgado is right, of course, but surely, reformists would argue, these "special burdens" are luxurious when compared to the burdens carried by Malcolm X, Dr. Martin Luther King, Jr., and other civil rights toilers. Some of us are quite willing to shoulder the sacrifices that are so much a part of our heritage. See, e.g., BROOKs, supra note 5, at 145-49 (discussing some aspects of African American heritage). We do it for "the cause."

151. Delgado, supra note 148 , at 1226-27.

152. Id. at 1225-26; see also Farber, supra note 134, at 908 (quoting this passage). 
action may be defensible as a device for bringing intellectual diversity to an institution. ${ }^{153}$ This is an important intellectual event which warrants further discussion.

Why the change of heart? Perhaps Professor Delgado has come to realize, as many reformists have, that for all its problems, affirmative action even as typically applied is the most effective device available for neutralizing, albeit not totally, the very racism whose permanency CRT announces at every opportunity. As one reformist, Professor Joel Kupperman, has said, perhaps with a bit of overstatement: "[T]he degree of conscious favoritism mandated by affirmative action programs has the effect of roughly cancelling out the effects of unconscious [or intentional institutional or individual] discrimination in the opposite direction." 154 And as Justice Brennan, a reformist most of the time, has said: "[A]ffirmative race-conscious relief may be the only means available 'to assure equality of employment opportunities and to eliminate those discriminatory practices and devices which have fostered racially stratified job environments to the disadvantage of minority citizens." "155

Finally, it may be that Professor Delgado has considered and rejected the types of observations presented in Professor Farber's important article on affirmative action. ${ }^{156}$ Farber suggests that the current level of affirmative action is likely to remain constant for both political and legal reasons. Moreover, he contends that affirmative action cannot address structural changes in the economy which conspire with our failed public schools to deny scores of African Americans opportunities for socioeconomic success. ${ }^{157}$

Professor Delgado may have responded to these arguments by demurrer. That is, like many reformists, he may have come to realize that affirmative action still has considerable value to those too few African Americans who are in a position to take advantage of the scarce opportunities available to them. ${ }^{158}$ Public and private studies since the 1960 s have repeatedly

153. See Richard Delgado, Rodrigo's Chronicle, 101 YaLE L.J. 1357, 1365-68 (1992) (book review); see also Farber, supra note 134, at 905 n.95 (citing this argument). Delgado's argument mirrors Professor Kennedy's argument in support of affirmative action. See supra note 8.

154. Brooks, supra note 113, at 356 (quoting Joel J. Kupperman, Relations Between the Sexes: Timely vs. Timeless Principles, 25 SAN Diego L. Rev. 1027, 1031 (1988) (alteration in originaI)).

155. Local 28 of the Sheet Metal Workers' Int'I Ass'n v. EEOC, 478 U.S. 421, 450 (1986) (quoting McDonnell Douglas Corp. v. Green, 411 U.S. 792, 800 (1973)). See generally Harry T. Edwards and Barry L. Zaretsky, Preferential Remedies for Employment Discrimination, 74 Mich. L. Rev. I (1975). Edwards and Zaretsky contend that "some form of 'color conscious' affirmative action must be employed in order to achieve equal employment opportunity for minorities and women." $1 d$. at 2.

156. Farber, supra note 134.

157. See generally id.

158. One of the authors of this Article has argued that the American race problem is not limited to poor or working class African Americans. Each socioeconomic class of African Americans has a unique set of racial problems. Moreover, each set of problems requires different remedial measures. Affirmative action is an appropriate remedial response to the problems of middle class African Americans but probably not to the problems of the African American poverty class. See Brooks, supra 
come to the same conclusion: affirmative action has "launched many qualified African Americans on successful careers they otherwise would not have entered or dared to pursue." 159 Indeed, it is likely that many middle class minorities who denounce affirmative action, having been helped by it at some point in their own successful careers, would not seriously advocate its abolition if they were just beginning the process themselves. ${ }^{160}$ This is especially true of those minorities who insist that racism is permanent.

Perhaps some or all of these considerations have contributed to Professor Delgado's apparent change of heart on reformist affirmative action. But to the extent that Professor Delgado supports affirmative action in some form, he would probably not endorse, as a reconstructive measure, an intermediate scrutiny test for affirmative action. In line with the other race crits, he would likely conclude that the lowest level of scrutiny offers the highest potential for minority empowerment. ${ }^{161}$

Having found some striking differences between CRT and classicalliberalism in the context of equal protection law, we now turn to another area for comparison: Title VII law.

\section{IV \\ Microtheoretical Differences: TitLe VII}

Title VII of the 1964 Civil Rights Act ${ }^{162}$ is the nation's major employment discrimination law. The legal framework established by the Supreme Court for addressing Title VII employment discrimination claims divides all such claims into two categories: "disparate treatment" and "disparate impact." Disparate treatment discrimination occurs when an employer treats some employees "less favorably than others because of their race, color, religion, sex, or national origin." 163 In contrast, disparate impact discrimination occurs when an employment practice, although facially neutral,

note 5, at I8, 39-5I, 152-57; see also Ellis Cose, The Rage of a Privileged Class (1993) (providing detailed examples of individual middle class African Americans' continuing struggle). That a remedy may have some success in one class but not in another does not diminish its value. It simply means that African Americans can no longer be viewed as a monolithic group.

159. Brooks, supra note 5, at 54.

160. They would probably recognize that affirmative action encourages institutions to recruit, hire, and promote minorities, even if in small numbers.

161. See supra text accompanying note 143 .

162. 42 U.S.C. $\$ \S 2000$ e to $2000 \mathrm{e}-17$ (I988 \& Supp. IV I992). Section 703(a) of Title VII provides:

It shall be an unlawful employment practice for an employer (1) to fail or refuse to hire or to discharge any individual, or otherwise to discriminate against any individual with respect to his compensation, terms, conditions, or privileges of employment, because of such individual's race, color, religion, sex, or national origin; or (2) to limit, segregate, or classify his employees or applicants for employment in any way which would deprive or tend to deprive any individual of employment opportunities or otherwise adversely affect his status as an employee, because of such individual's race, color, religion, sex, or national origin.

42 U.S.C. \$ 2000e-2(a) (1988).

163. Intemational Bhd. of Teamsters v. United States, 431 U.S. 324, 335 n.15 (1977). 
"fall[s] more harshly on one group than another."164 Thus, while disparate treatment claims require proof of racial motivation, disparate impact claims do not. ${ }^{165}$

In this Part, we shall attempt to determine whether CRT's macrotheoretical perspective on civil rights ${ }^{166}$ provides an analysis of specific Title VII legal doctrines that differs from classical-liberal analysis of such doctrines. We have chosen two Title VII doctrines for this inquiry: accent discrimination (Section A) and intersectionality (Section B). Although we will follow the basic methodology established in Part III, comparing CRT with the traditionalists' and reformists' perspectives, we will need to be even more inventive in our discussion of certain aspects of classical-liberal analysis. Unfortunately, there is a dearth of relevant classical-liberal scholarship on which we can draw. Finally, we shall discuss, in Section C, a umque CRT proposal: the abolition of Title VII.

\section{A. Accent Discrimination}

Courts generally recogmize that discrimination on the basis of a foreign trait, such as accent, is actionable under Title VII as discrimination on the basis of national origin. ${ }^{167}$ A plaintiff seeking to prove accent discrimination typically seeks to establish a prima facie case by showing that: 1) he or she has an identifiable national origin; 2 ) he or she applied and was qualified for a job for which the employer was seeking applicants; 3 ) he or she was rejected despite being qualified; and 4) after the rejection, the position remained open, and the employer continued to seek applicants from persons with the plaintiff's qualifications. ${ }^{168}$

Once the plaintiff establishes a prima facie case, the burden of production shifts to the employer "to rebut the presumption of discrimination by 'articulating some legitimate, nondiscriminatory reason' for the adverse action." 169 If the employer presents such a reason, the burden of production shifts back to the plaintiff, who must show that the employer's purported reason for rejecting the plaintiff was merely "a pretext for discrimina-

164. Id. at 336 n.15.

165. Id. at 335 n. 15 .

166. See supra Part II.

167. For cases analyzing accent discrimination claims under the Title V1l standards of national origin discrimination, see Fragante v. City of Honolulu, 888 F.2d 591 (9th Cir. 1989), cert. denied, 494 U.S. 1081 (1990); Carino v. University of Okla. Bd. of Regents, 750 F.2d 815 (10th Cir. 1984); Berke v. Ohio Dep't of Pub. Welfare, 628 F.2d 980 (6th Cir. 1980) (per curiam); Bell v. Home Life Ins. Co., 596 F. Supp. 1549 (M.D.N.C. 1984). The EEOC's definition of national origin discrimination includes "the denial of equal employment opportunity . . . because an individual has the physical, cultural or linguistic characteristics of a national origin group." 29 C.F.R. $\$ 1606.1$ (1993) (emphasis added).

168. Fragante, 888 F.2d at 595; see also McDonnell Douglas Corp. v. Green, 411 U.S. 792, 802 (1973) (applying the same test in the context of racial discrimination). Most accent discrimination cascs are disparate treatment cases.

169. Fragante, 888 F.2d at 595 (quoting Texas Dep't of Community Affairs v. Burdine, 450 U.S. 248,254 (1981)). 
tion."170 Although the burden of production shifts between the plaintiff and defendant, the burden of persuasion as to all elements remains on the plaintiff. ${ }^{171}$

\section{Traditionalists' Approach}

Fragante v. City of Honolulu ${ }^{172}$ is perhaps the most prominent exainple of the standard approach to Title VII accent cases. Manuel Fragante was born in the Philippines, but he received most of his schooling in English. ${ }^{173} \mathrm{He}$ emigrated to Hawaii at the age of sixty and applied for a job as an entry level clerk at the Honolulu Division of Motor Vehicles. ${ }^{174}$ Although he scored the highest of 721 applicants on a civil service exam which tested word usage, grammar, and spelling, he was not selected for the clerk position because of a perceived deficiency in communication skills caused by his " 'heavy Filipino accent." "175 Fragante's communication skills were assessed in an interview. After the interview, he dropped from number one to number three on the list of eligible candidates. ${ }^{176}$ The two other applicants, who were judged more qualified than Fragante, were offered the two available jobs. ${ }^{177}$

After exhausting his administrative remedies, ${ }^{178}$ Fragante filed a Title VII claim in the district court alleging accent discrimination under a disparate treatment theory. ${ }^{179}$ The district court dismissed his complaint, ${ }^{180}$ holding that the city's rejection of Fragante because of his accent was permissible under Title VII's bona fide occupational qualification ("BFOQ") defense. ${ }^{181}$ In the district court's judgment, clear and effective communica-

170. Burdine, 450 U.S. at 253. A plaintiff may establish pretext by showing that the employer was more likely motivated by a discriminatory reason or by showing that the employer's proffered reason is not worthy of belief. Id. at 256.

171. Id. at 253; St. Mary's Honor Ctr. v. Hicks, 113 S. Ct. 2742, 2747-48 (1993).

172. 888 F.2d 591 (9th Cir. 1989), cert. denied, 494 U.S. 1081 (1990).

173. Fragante v. City of Honolulu, 699 F. Supp. 1429, 1429 (D. Haw. 1987), aff'd, 888 F.2d 591 (9th Cir. 1989), cert. denied, 494 U.S. 1081 (1990).

174. Fragante, 888 F.2d at 593.

175. Id. at 593-94.

176. Id. at 594 .

177. Id.

178. A person claiming to be aggrieved by a discriminatory act in violation of Title VII must exhaust the administrative remedies set forth in the statute before he may file a civil lawsuit under Title VII. 42 U.S.C. $\$ 2000 \mathrm{e}-5(f)(1)(1988)$. The aggrieved party must first file timely charges with the state, if applicable, and with the EEOC. 42 U.S.C. $\$ 2000$ e-5 (1988 \& Supp. IV 1992). Mr. Fragante sued the city after being notified that the EEOC had found that the city had not discriminated against him. Fragante v. City of Honolulu, 699 F. Supp. at 1432 (D. Haw. 1987), aff'd, 888 F.2d 591 (9th Cir. 1989), cert. denied, 494 U.S. 1081 (1990).

179. Id. at 1429 .

180. Id. at 1432 .

181. Id. Title VII provides, in pertinent part:

[I]t shall not be an unlawful employment practice for an employer to hire and employ ... on the basis of his religion, sex, or national origin in those certain instances where religion, sex, or national origin is a bona fide occupational qualification reasonably necessary to the normal operation of that particular business or enterprise .... 
tion with the public was a BFOQ for the particular position Fragante sought. ${ }^{182}$ Although the court noted that he had "extensive verbal communication skill in English," 183 it also found that his "difficult manner of pronunciation"184 amply supported the city's BFOQ defense. Fragante appealed to the Ninth Circuit Court of Appeals.

The Ninth Circuit unanimously affirmed the trial court's decision. But rather than basing its ruling on the BFOQ defense, the Ninth Circuit held that the city had articulated a "legitimate, nondiscriminatory reason" for rejecting Fragante ${ }^{185}$ and that the reason was not a mere pretext for unlawful discrimination. ${ }^{186}$ Fragante "was passed over because of the deleterious effect of his Filipino accent on his ability to communicate orally, not merely because he had such an accent."187

No prominent commentator has defended Fragante. Based on the case's macroperspective on civil rights, however, a traditionalist might defend the Ninth Circuit's decision on at least two grounds. First, Fragante may be embraced because it accepts the conceptual soundness of FEO, the nation's fundamental civil rights policy. Honolulu had no official policy excluding people with heavy Filipino accents from city jobs, as might have been the case under the separate-but-equal civil rights policy. ${ }^{188}$ To the contrary, Fragante was allowed to apply for the job and went through the same application process as everyone else. Thus, traditionalists might conclude that the Ninth Circuit correctly focused on the fact that Fragante received procedurally equal treatment. The city rejected him, not merely because he had an accent, but because it had reasonable business concerns about the impact his accent might have on his ability to communicate orally. So understood, the Ninth Circuit's decision arguably vindicates the traditional FEO principle, which requires only that people be evaluated through similar procedures. ${ }^{189}$

Second, traditionalists might also defend Fragante on a less conceptual level by maintaining that the decision represents a correct application

42 U.S.C. $\S 2000 \mathrm{e}-2(\mathrm{e})(1)(1988)$.

182. Fragante, 699 F. Supp. at 1432.

183. Id. at 1431 .

184. Id. at 1432 .

185. Fragrante, 888 F.2d at 596 .

186. Id. at 598. Like any Title VII affirmative defense, the BFOQ defense comes into play only if the plaintiff proves pretext. Thus, once the plaintiff establishes that the defendant's "legitimate, nondiscriminatory reason" is merely an attempt to cover up his or her use of an impermissible motivation, the plaintiff proves employment discrimination. The defendant ean still avoid Title V11 liability by establishing a Title VII affirmative defense. For a thorough discussion of the Title VII evidentiary scheme, see Roy L. Brooks, The Structure of Individual Disparate Treatment Litigation After Hopkins, 6 LAB. Law. 215, 227-31 (1990).

187. Fragante, $888 \mathrm{~F} .2 \mathrm{~d}$ at 599.

188. See supra text accompanying notes 20-26.

189. A traditionalist might also argue that Congress structured Title VII so that business-related considerations could be taken into account without violating the concept of FEO. By refusing to tinker with the structure of Title VII, the Fragante court respected the will of Congress. 
of the FEO principle. This defense would emphasize that the Ninth Circuit based its decision on the importance of efficient oral communication for successful performance as a DMV clerk. To the extent that Fragante's accent might have interfered with optimal communication because, for example, he might have to repeat himself or speak more slowly or spell words, the accent interfered with his abihty to perform the job efficiently and with minimal supervision. Thus, traditionalists would applaud the court's application of FEO in this case.

That plaintiffs have won other accent discrimination cases using the very same legal framework under which Fragante lost ${ }^{190}$ also supports the traditionalists' argument that Fragante correctly applied the FEO principle. The success of other plaintiffs suggests that the court's symmetrical application of Title VII's anti-discrimination law to the problem of accent discrimination was basically sound. Mr. Fragante lost because he had a weak case; the FEO framework may be trusted to adequately protect those with stronger cases. ${ }^{191}$

\section{Reformists' Approach}

The paucity of reformist scholarship on accent discrimination law under Title VII makes it difficult to compare the CRT and reformist perspectives. However, given CRT's minority-sensitive orientation, it is not surprising that the topic has attracted less attention from reformists. Nor is it surprising that a race crit, Professor Mari Matsuda, was the first legal scholar to provide an in-depth discussion of the problem of accent discrimination. ${ }^{192}$ Nevertheless, by drawing on the macrotheoretical differences

190. See, e.g., Carino v. University of Okla. Bd. of Regents, 750 F.2d 815 (10th Cir. 1984); Berke v. Ohio Dep't of Pub. Welfare, 628 F.2d 980 (6th Cir. 1980); Xieng v. Peoples Nat'l Bank, 844 P.2d 389 (Wash. 1993) (applying a Washington law modeled after Title VII).

191. A traditionalist would point out that the two candidates who received job offers in the end were rated higher in terms of communicative ability and thus could, in all likelihood, perform the clerk job more efficiently.

192. See infra text accompanying notes 199-217. Juan Perea at Florida has done highly regarded work on related themes. See Juan F. Perea, Demography and Distrust: An Essay on American Languages, Cultural Pluralism, and Official English, 77 MinN. L. REv. 269 (1992) (discussing the pervasiveness of linguistic diversity in American history and arguing that English-only laws are motivated by nativism and violate equal protection); Juan F. Perea, English-Only Rules and the Right to Speak One's Primary Language in the Workplace, 23 U. MrcH. J.L. REF. 265 (1990) (arguing that speaking one's primary language at work should constitute a protected right under Title VII and advocating the use of a stricter standard to evaluate an employer's business justification defense). The specific topic of accent discrimination has been left largely to student notes and comments. See, e.g., Carolyn Ratti Matthews, Comment, Accent: Legitimate Nondiscriminatory Reason or Permission to Discriminate?, 23 ARIz. ST. L.J. 231 (1991) (suggesting an alternative legal standard for deciding Title VII accent discrimination cases); Beatrice B. Nguyen, Comment, Accent Discrimination and the Test of Spoken English: A Call for an Objective Assessment of the Comprehensibility of Nonnative Speakers, 81 CaLif. L. Rev. 1325 (1993), 1 Asian L.J. 117 (1994) (offering the Test of Spoken English as an objective tool for courts to use in accent discrimination cases); see also Stephen M. Cutler, Note, $A$ Trait-Based Approach to National Origin Claims Under Title VII, 94 YALE LJJ. 1164 (1985) (attacking current enforcement of Title VII as discriminatory against culturally unassimilated members of a national origin group). 
discussed earlier, ${ }^{193}$ it is possible to compensate for the lack of reformist scholarship and to formulate a reformist critique of Fragante.

Reformists might both defend and attack the result in Fragante. Proceeding from their assumption that FEO is conceptually sound, reformists might find judicial expression of that concept in the Fragante court's support of linguistic tolerance. The Ninth Circuit began its legal analysis by emphasizing the importance of treating people with equal respect irrespective of accent:

Preliminarily, we do well to remember that this country was founded and has been built in large measure by people from other lands, many of whom came here-especially after our early beginnings-with a limited knowledge of English. This flow of immigrants has continued and has been encouraged over the years. From its inception, the United States of America has been a dream to many around the world. We hold out promises of freedom, equality, and economic opportunity to many who only know these words as concepts. ${ }^{194}$

This passage suggests an appreciation for the need to respect difference in immigrants like Mr. Fragante so that equality and freedom will be equally distributed.

Reformists would probably also appreciate the court's explicit attempt to limit its decision to the facts presented. Although it found that Fragante was treated fairly, the Ninth Circuit urged other courts to be careful not to let employers hide behind communication ability as a pretext for unlawful discrimination. ${ }^{195}$ This admonition would probably appeal to the reformists' belief in FEO since it appears to demonstrate the court's commitment to the primciples of linguistic tolerance and equal legal treatment.

On the other hand, reformists might be critical of certain aspects of the Fragante decision, and of certain elements of accent discrimination law generally. For example, reformists would probably urge closer judicial scrutiny of the city's "legitimate nondiscriminatory reason"196 for rejecting Fragante. Closer scrutiny is necessary, the argument would run, because otherwise an employer who contends that an accent interferes with job ability will win almost every time. Employers can easily hide behind performance-related pretexts if their discriminatory behavior is merely subjected to some sort of formalistic rational basis test.

Thus, to prevent perverse implementation of FEO in accent discrimination cases, reformists would insist that courts scrutinize these cases more

193. See supra text accompanying notes $40-43$.

. 194. Fragante v. City of Honolulu, 888 F.2d 591, 596 (9th Cir. 1989), cert. denied, 494 U.S. 1081 (1990). Because traditionalists share the reformists' belief in FEO, they would also embrace this passage.

195. Id.

196. See id. 
closely. This could be accomplished by asking two questions: Is rapid communication essential to the safe and profitable performance of the job in question? More generally, was the plaintiff given a fair evaluation?

Reformists' reconstructive analysis might also recommend that Title VII plaintiffs like Fragante be freed from the burden of proving pretext. Fragante and other similarly-situated plaintiffs have an extremely difficult time proving intentional discrimination because it is hard to discover or prove what is in another person's, let alone a city's, heart or mind. ${ }^{197}$ Therefore, reformists might reason, defendants, who have superior access to the relevant information, should bear the burden of disproving discriminatory intent. ${ }^{198}$

In sum, reformists would probably join traditionalists in defending Fragante's underlying commitment to equal treatment and linguistic tolerance but would advocate tinkering with the rules to achieve those goals more effectively.

\section{CRT's Approach}

Professor Mari Matsuda, a powerful proponent of CRT, agrees with the reformists' observation that accent discrimmation doctrine is flawed in its implementation. ${ }^{199}$ Unlike the reformists, however, Matsuda contends that these implementation problems derive, at least in part, from conceptual flaws in the FEO principle. Thus, even if FEO were effectively deployed, courts would still only be looking for glaring examples of conscious bias in accent discrimination cases. This approach would not solve the problem, Matsuda argues, because accent discrimination most often results from unconscious bias:

A major complicating factor in applying Title VII to accent cases is the difficulty im sorting out accents that actually impede job performance from accents that are simply different from some preferred norm imposed, whether consciously or subconsciously, by the employer. The reality that accent discrimination is often unconscious, [sic] renders the judical search for pretext pointless. Pretext by definition involves a conscious choice to discriminate. ${ }^{200}$

Commenting on Fragante and other cases, Professor Matsuda continues:

Caught in the existing doctrinal emphasis on a search for "pretext," however, [these courts] missed the reality of how linguistic discrimination works. It works not through pretext, but through a set of ingrained prejudices and assumptions that are inevitably lodged in

197. See supra text accompanying notes 93-96.

198. See Brooks, supra note 5, at 153-54.

199. See Matsuda, Voices of America, supra note 3, at 1350 ("The problem is that in every accent case the employer will raise the 'can't understand' defense, and in almost every reported case, the courts have accepted it.").

200. Id. at 1352 (emphasis added). 
the process of evaluation and in the ways in which we assign values like "difficult," "standard," and "intelligible" from our own vantage point. 201

Professor Matsuda also applies concepts of sociolinguistics to show that our society has constructed a "status hierarchy of accents"202 that tends to subordinate some accents ${ }^{203}$ and elevate others. ${ }^{204}$

Professor Matsuda's deconstructive analysis differs appreciably from the reformists' in at least two ways. First, she unabashedly states that her critique is "explicit, partisan, and non-neutral in its commitment to the ends of dismantling structures of subordination and promoting radical pluralism."205 In other words, Matsuda deliberately asks "the subordination question" and seeks to understand accent discrimination from the perspective of the oppressed rather than from that of employers or judges. ${ }^{206}$

Second, Professor Matsuda provides a more contextualized analysis of accent discrimination. She achieves this contextualization in two ways. First, she borrows from sociolinguistics to demonstrate that much of our evaluation of intelligibility is driven by unconscious prejudice. ${ }^{207}$ She also uses a great deal of narrative in her analysis to illustrate the degree to which accent discrimination is a normal, ordinary, and natural feature of our lives and to display empathy for plaintiffs like Fragante. ${ }^{208}$

Because Professor Matsuda believes accent discrimination is pervasive in our society, ${ }^{209}$ her proposal for revising Title VII accent discrimination doctrine is concomitantly far-reaching in scope. She proposes that courts conduct a four-part inquiry in all Title VII accent discrimination cases:

1. What level of communication is required for the job?

2. Was the candidate's speech fairly evaluated?

3 . Is the candidate intelligible to the pool of relevant, nonprejudiced listeners, such that job performance is not unreasonably impeded?

201. Id. at 1387 (emphasis added).

202. Id. at 1367.

203. Cf. id. at 1360 (discussing Matsuda's own experience subordinating the manner of deaf communication).

204. An example is the "so-called standard American accent." Id. at 1361.

205. Id. at 1393.

206. Id. at 1330 ("[This Article] looks for the coercive and hidden assumptions embedded in law, and values the multiple consciousness of the disempowered.").

207. Id. at 1360-67.

208. Id. at 1332 ("This Article opens with stories of some of the accents that gave rise to the existing judicial decisions."), 1333-48. For criticism of Professor Matsuda's narrative methodology, see Daniel A. Farber \& Suzanna Sherry, Telling Stories out of School: An Essay on Legal Narratives, 45 Stan. L. Rev. 807, 852 n.237 (1993) (suggesting that Professor Matsuda's narrative lcaves out ccrtain facts that do not fit her "saga of elite domination"); Matthew W. Finkin, Refections on Labor Law Scholarship and Its Discontents: The Reveries of Monsieur Verog, 46 U. MiamI L. Rev. 1101, 1138-43 (1992) (criticizing Matsuda's use of narrative and arguing that "[l]egal concepts, not stories, separato the meaningful from the irrelevant").

209. See Matsuda, Voices of America, supra note 3, at 1348. 
4. What accommodations are reasonable given the job and any

limitations in intelligibility? ${ }^{210}$

Professor Matsuda's first three questions are both old and new. She admits that they are simply logical applications of current doctrine. ${ }^{211}$ In that sense, reformists probably would not quarrel with them. On the other hand, the fourth question's "reasonable accommodation" principle injects an unprecedented level of scrutiny into Title VII cases like Fragante. ${ }^{212}$ It would require a court to ask "whether the employer can make reasonable changes in the workplace that would increase communication within the relevant listener pool."213 The reasonable accommodation principle flows logically from Professor Matsuda's observation that unconscious bias in accent evaluation is ingrained in our society and thus is often impossible to eliminate. Given that reality, she argues, employers should be required to make cost-effective adjustments in order to accommodate speech differences. ${ }^{214}$

The reasonable accommodation principle also follows logically from the CRT conception of racial equality, which treats colorblindness as an inadequate solution. ${ }^{215}$ In the same vein, Professor Matsuda rejects the desirability of linguistic sameness. ${ }^{216}$ She argues that Title VII law should celebrate differences in accent and empower those with nonstandard accents to succeed within the employment milieu. Professor Matsuda contends, for example, that the Honolulu DMV could have accommodated Fragante's Filipino accent by altering its "procedures, written information, and staffing" or by directing "turned-off" listeners to other clerks. ${ }^{217}$

In the area of accent discrimination, then, we see substantial microtheoretical differences between CRT and classical-liberalism. Traditionalists most likely would view the current Title VII framework as conceptually coherent and workable. Reformists would consider it conceptually coherent but largely unworkable because it does not give sufficient attention to those with nonstandard accents. Such consideration, the reformists would argue, could be achieved by incremental microreforms. Finally, race crits such as Professor Matsuda view Title VII accent discrimination law as both conceptually incoherent and practically unworkable as a means of ending subordi-

210. Id. at 1368.

211. Id.

212. Id. ("The reasonable accommodation language is an element that goes beyond existing Title VII doctrine."). The principle is not new to law in general. Professor Matsuda stresses that she has borrowed the concept from disability law. Id.

213. Id. at 1379.

214. Id. at 1379-80. Examples of cost-effective techniques are visual back-ups, written memos, pictographs, sign language, and training. Id. at 1380.

215. See supra text accompanying note 50 .

216. Matsuda, Voices of America, supra note 3, at 1407 ("Each American can trace back to an ancestor who spoke with a different voice.... It is a joy of our heritage, not a shame, that in our mixing of language and sound we were ever inventive and changeable.") (footnote omitted).

217. Id. at 1386. 
nation. The existing legal regime does not address unconscious bias, and it assumes the desirability of linguistic sameness.

\section{B. Intersectionality}

A second aspect of Title VII law is also relevant for our comparison of classical-liberal and CRT scholarship. The CRT doctrine of "intersectionality," which has become closely associated with Professor Kimberlé Crenshaw, ${ }^{218}$ attempts to integrate into employment discrimination law the actual experiences of an outsider group, in this instance, the experiences of African American women. Intersectionality posits that African American women share unique life experiences that differ from those of either African American men or white women. The doctrine places the experiences of African American women at the intersection of race and gender. Professor Crenshaw argues that Title VII antidiscrimination law is dominated by a "single-axis framework" that fails to recognize discrimination against such intersectional groups. ${ }^{219}$ Thus, race crits use the doctrine as a baseline from which to critique existing antidiscrimination law.

Although the differences between traditionalists and race crits are vast when it comes to intersectionality, the differences between reformists and race crits are less striking than in the areas of civil rights law previously analyzed. We start with the traditionalist approach to intersectionality.

\section{Traditionalists' Argument Against Intersectionality}

The traditionalist approach to the claims of African American women plaintiffs (i.e., intersectionality claims) under Title VII has been to deny these plaintiffs standing to bring a combined sex discrimination and race discrimination claim. This approach limits African American women plaintiffs to either bringing a race or sex discrimination claim on its own or bringing alternative claims of race discrimination and sex discrimination. DeGraffenreid v. General Motors Assembly Division ${ }^{220}$ exemplifies the traditional approach. In DeGraffenreid, African American women employees of General Motors challenged the company's seniority system based on a combination of sex and race discrimination. ${ }^{221}$ The court observed that "this lawsuit must be examined to see if it states a cause of action for race discrimination, sex discrimination, or alternatively either, but not a combination of both."222 Dismissing the sex discrimination claim on a motion for

218. See Crenshaw, Demarginalizing the Intersection of Race and Sex, supra note 3.

219. Id. at 140 .

220. 413 F. Supp. 142 (E.D. Mo. 1976), aff'd in part and rev'd in part, 558 F.2d 480 (8th Cir. 1977).

221. Id. at 143 .

222. Id. 
summary judgment, the court then ruled that the plaintiffs could bring only a race discrimination claim. ${ }^{223}$

A fairly sophisticated defense of DeGraffenreid can be constructed from the traditionalists' macroperspective on civil rights. ${ }^{224}$ By denying the sex discrimination claim, the decision ensures equal treatment under Title VII for everyone regardless of race or sex. Judicial recognition of intersectionality claims would give African American women plaintiffs enhanced standing in the form of an additional claim based on a combination of race and sex discrimination. In effect, traditionalists would argue, African American women would have a "super-remedy" that other Title VII claimants would not have. As the DeGraffenreid court noted: "The legislative history surrounding Title VII does not indicate that the goal of the statute was to create a new classification of 'black women' who would have greater standing than, for example, a black male."225 African American women plaintiffs, traditionalists might argue, already have two distinct claims available to them under Title VII (race or sex). These plaintiffs should not receive an additional claim simply based on both race and sex.

Traditionalists might raise two additional objections to allowing plaintiffs to bring intersectionality claims. First, plaintiffs could create multiple status combinations that would expand opportunities to sue their employers (e.g., "black Catholic women plaintiffs" or "black Cuban men plaintiffs"). Indeed, the DeGraffenreid court found this argument persuasive: "The prospect of the creation of new classes of protected minorities, governed only by the mathematical principles of perinutation and combination, clearly raises the prospect of opening the hackneyed Pandora's box."226 Traditionalists might fear that multiple status claims could stretch Title VII's application beyond reason. Employers could not make any employment decision without fear of facing a discrimination claim by a member of a subgroup at every turn. Not only could this subject the employer to increased liability, ${ }^{227}$ it could also create evidentiary and administrative difficulties. $^{228}$

Second, traditionalists would probably argue that judicial recognition of a cause of action for multiple status claims constitutes unwarranted judicial intrusion into the legislative domain. Even reformist critics of DeGraffenreid concede that Congress has not provided clear guidance on

223. Id. at 144-45.

224. See supra text accompanying notes 36-39.

225. DeGraffenreid, 413 F. Supp. at 145.

226. Id.

227. Since 1991, a prevailing Title VII plaintiff may recover compensatory damages (including emotional pain, suffering, mental anguish, and "other nonpecuniary losses") and punitive damages, which are capped at certain levels. 42 U.S.C. $\$ 1981$ a (Supp. IV 1992).

228. A Title VII plaintiff seeking compensatory and pnnitive damages has a right to a jury trial. Id. $\S 1981 \mathrm{a}(\mathrm{c})$. 
this issue either in the text of the statute or in the legislative history. ${ }^{229}$ Given congressional ambivalence, the traditionalists would likely conclude that it is inappropriate for courts to create this complex cause of action. Congress, they would argue, is better suited to that task.

\section{Reformists' Argument for Intersectionality}

While we have had to speculate how traditionalists might defend DeGraffenreid based on their fundamental civil rights perspective, the reformists' response to DeGraffenreid is clear. Reformists view the decision in that case as a prime illustration of how conceptually sound civil rights policy is foolishly implemented.

DeGraffenreid improperly applies FEO, reformists argue, because it ignores the fact that African American women are a discrete group with a unique history and burdened with unique difficulties. For example, Professor Elaine Shoben argues that "[t]he simple dichotomies of male/ female or black/white are often insufficient to describe the unique problems faced by compound groups such as black women."230 Reformists point out that, unlike white women and African American men, African American women do not possess a characteristic traditionally associated with power (whiteness or maleness). Moreover, African American women combat special stereotypes that make them particularly vulnerable to employment discrimination. Professor Judith Winston writes:

In the days of slavery in the United States, both white men and white women often regarded black women as little more than breeding factories for producing free labor. White society created myths to justify their oppression and exploitation, portraying black women as fecund and promiscuous objects, available to satisfy white male sexual desires.

... Myths die hard. The modern versions of these superstitions have become entrenched in countless areas of American life, particularly in the workplace, where these attitudes are often manifested as race and gender harassment. ${ }^{231}$

The complex interaction of race and gender myths, reformists argue, translates into a dual stigma that relegates African American women to the bot-

229. Elaine W. Shoben, Compound Discrimination: The Interaction of Race and Sex in Employment Discrimination, 55 N.Y.U. L. REv. 793, 799-802 (1980) (suggesting that the validity of a cause of action for intentional compound discrimination is not clear from the text of Title VII but is derived from "meager legislative history" and judicial assumptions).

230. Id. at 834-35.

231. Judith A. Winston, Mirror, Mirror on the Wall: Title VII, Section 1981, and the Intersection of Race and Gender in the Civil Rights Act of 1990, 79 CALIF. L. REv. 775, 784-86 (1991) (footnotes omitted). 
tom by almost every socioeconomic indicator. ${ }^{232}$ Therefore, the civil rights interests of African American women should be given greater deference under Title VII law.

Reformists, in short, criticize DeGraffenreid for its failure to recognize compound discrimination ${ }^{233}$ as a subtle yet potent form of discrimination actionable under Title VII. In the case of African American women, reformists realize that compound discrimination is not premised on race or sex alone but results instead froin a synergy of these two factors. This point can be further illustrated with a hypothetical. Assume that a corporation requires its applicants to sit for oral interviews in which they are subjectively rated on qualities such as "fits the corporate profile," "leadership potential" or "ability to project a commanding presence." Also assume that African American women disproportionately fail the interview while African American men and white women score exceptionally well. In such a case, it would seem that stereotypes of African American women have disadvantaged them as a distinct group. ${ }^{234}$ Understood in this manner, compound discrimination claims are not reducible to either of the contributing factors (e.g., race or sex) but are instead attributable to the combined effects of both.

Moving from a deconstructive to a reconstructive analysis, reformists suggest that courts should uniformly recognize a Title VII compound discrimination cause of action. ${ }^{235}$ Compound causes of action are cognizable under established Title VII precedent. ${ }^{236}$ Moreover, several courts have allowed African American women to state Title VII claims based on compound discrimination. ${ }^{237}$ Reformists argue that these decisions, even if not

232. Id. at 778-80; Judy Trent Ellis, Sexual Harassment and Race: A Legal Analysis of Discrimination, 8 J. LeGrs. 30, 39-41 (1981).

233. See Shoben, supra note 229, at 796 n.10 (defining compound discrimination "as the interaction of any two groups covered by Title VII").

234. This example is loosely based on the facts of Harless v. Duck, 619 F.2d 611, 616 (6th Cir.), cert. denied, 449 U.S. 872 (1980).

235. Ellis, supra note 232, at 32; Shoben, supra note 229, at 798; Winston, supra note 231, at 799801.

236. It seems clear that the inclusion of the word "or" in the list of characteristics in $\$ 703(a)$, see supra note 162, means "either or both" rather than "one but not the other." As one court has observed, " $[t]$ he use of the word 'or' evidences Congress' intent to prohibit employment discrimination based on any or all of the listed characteristics." Jefferies v. Harris County Community Action Ass'n, 615 F.2d 1025, 1032 (5th Cir. 1980); see also 110 Cong. Rec. 2728 (1964) (rejecting Congressman Dowdy's proposed amendment, which would have added the word "solely" to modify the list of characteristics).

237. One of the first such cases was Jefferies v. Harris County Community Action Ass'n, 615 F.2d I025 (5th Cir. 1980). Every court that has ruled on the issue since Jefferies has rejected DeGraffenreid and held that black women can claim Title VII protection as a distinct hybrid group. See, e.g., Judge v. Marsh, 649 F. Supp. 770, 779-80 (D.D.C. 1986) (agreeing with Jefferies' "sex-plus" analogy, discussed infra this note); Chambers v. Omaha Girls Club, 629 F. Supp. 925, 944 n.34 (D. Neb. 1986), aff'd 834 F.2d 697 (8th Cir. 1987) (same); Graham v. Bendix Corp., 585 F. Supp. 1036, 1047 (N.D. Ind. 1984) (citing and agreeing with Jefferies).

Other courts have allowed African American women to bring class claims without even addressing the issue. See, e.g., Lewis v. Bloomsburg Mills, Inc., 773 F.2d 561, 566 (4th Cir. 1985). The Lewis court simply assumed that African American women were a protected class. 
perfect, are more just to African American women than the traditionalist approach because they proceed from the correct assumption that discrimination against African American women can differ from discrimination against African American men or white women. Such thinking, reformists suggest, will lead to more effective implementation of FEO for African American women under Title VII. ${ }^{238}$

Responding to the traditionalists' concern about expanding Title VII's application beyond appropriate boundaries, ${ }^{239}$ reformists remind us that courts long ago allowed white men to bring "reverse discrimination" claims even though such claims allege discrimination on the basis of two characteristics, race and sex. ${ }^{240}$ Reformists also suggest that courts could restrict to two the number of compound permutations that Title VII would recogmize in a disparate impact case. ${ }^{241}$ Under this proposal, a "black Cuban Catholic woman plaintiff would have to choose two factors she wishes to compound (for instance, sex and ethnicity), not four (race, ethnicity, religion, and sex).

Our analysis clearly reveals the contrasting views of traditionalists and reformists on the intersectionality issue. Traditionalists, arguing that FEO

The Jefferies court justified its holding, in part, by referring to the "sex-plus" cases. 615 F.2d at 1033. In these cases, the Supreme Court and other courts held that discrimination against certain subclasses of women violated Title VII. See Phillips v. Martin Marietta Corp., 400 U.S. 542, 544 (1971) (per curiam) (holding that, absent business necessity, a company's refusal to hire women with preschool-age children, while hiring similarly situated men, was sex-based discrimination prohibited by Title VII); In re Consolidated Pretrial Proceedings in the Airline Cases, 582 F.2d 1142, 1145 (7th Cir. 1978) (holding that a policy requiring female cabin attendants with children to accept ground duty positions was "a clear example of sex discrimination"), rev'd on other grounds sub nom. Zipes v. Trans World Airlines, Inc., 455 U.S. 385 (1982). Both reformists and race crits rightly point out that "sexplus" reasoning does not involve two separate claims of employment diserimination. Instead, "sex-plus" analysis involves a singular claim of discrimination based on sex plus a neutral faetor. Both reformists and race crits suggest that African American women should be treated as a separate and independent group of claimants in a compound case, not as a subset of women or African Americans. See Crenshaw, Demarginalizing the Intersection of Race and Sex, supra note 3, at 139-40. For a reformist rejection of the application of sex-plus analysis to compound discrimination claims, see Shoben, supra note 229, at 803-05.

In Connecticut v. Teal, 457 U.S. 440,455 (1982), the Court ruled that:

Title VII does not permit the victim of a facially discriminatory policy to be told that he has not been wronged because other persons of his or her race or sex were hired. That answer is no more satisfactory when it is given to victims of a policy that is facially neutral but practically diseriminatory.

Thus, whether women as a group or African Americans as a group experience discrimination should not determine whether an African American woman has a claim of individual disparate treatment or disparate impact discrimination under Title V11. See also ARTHUR B. SMITH, JR. ET AL., EMPLOYMENT Discrimination Law: Cases And Materials 353 n.3 (2d ed. 1982) (discussing Jefferies and contending that "even without a showing of pure race or sex discrimination, if it can be demonstrated that the plaintiff was treated differently by her employer because she is a black woman, she would be entitled to Title VII relief").

238. See Shoben, supra note 229, at 834-36.

239. See supra text accompanying notes 226-28.

240. See id. at 797-98 ("Courts addressing reverse discrimination claims generally have assumed without discussion that the compound category of white males is protected by the Aet.").

241. Id. at 807,821 . 
is sensible both in concept and as initially implemented in DeGraffenreid, reject intersectionality. They support an application of Title VII that would limit all plaintiffs, including African American women, to single-axis claims. According to traditionalists, equality of treatment requires that African American women receive no special treatment and that competing concerns (i.e., concerns of employers and "process" concerns) be honored. Reformists, on the other hand, embrace intersectionality and believe that courts should give greater deference to the special civil rights interests of African American women. Hence, reformists contend that courts should apply Title VII to compound discrimination claims.

\section{CRT's Argument for Intersectionality}

Professor Crenshaw's CRT critique of DeGraffenreid mirrors that of the reformists. She begins with the recognition that African American women share unique life experiences that lie at the intersection of race and gender. ${ }^{242}$ These experiences, she argues, cannot be fully understood without considering both race and gender. Thus, she criticizes DeGraffenreid for pigeonholing discrimination claims brought by African American women into either race-based or sex-based classifications. As she writes: "In DeGraffenreid, the court refused to recognize the possibility of compound discrimination against Black women and analyzed their claim using the employment of white women as the historical base. As a consequence, the employment experiences of white women obscured the distinct discrimination that Black women experienced." 243

242. See Crenshaw, Demarginalizing the Intersection of Race and Sex, supra note 3, at 152-60 (noting that feminist theory has tended to ignore the unique combination of race and gender issues faced by African American women). Professor Crenshaw has also investigated the connections between race and gender outside the Title VII context. See Kimberle Crenshaw, Mapping the Margins: Intersectionality, Identity Politics, and Violence Against Women of Color. 43 STAN. L. Rev. 1241 (1991) (discussing race and gender as intersecting aspects of violence against women of color). For other work in a similar vein, see Regina Austin, Sapphire Bound!, 1989 W1s. L. REv. 539 (applying an African American feminist perspective to Chambers v. Omaha Girls Club, 629 F. Supp. 925 (D. Neb. 1986), aff'd, 834 F.2d 697 (8th Cir. 1987)); Paulette M. Caldwell, A Hair Piece: Perspectives on the Intersection of Race and Gender, 1991 Duke L.J. 365 (discussing the failure of courts to account for race-sex interaction in the context of Rogers v. American Airlines, 527 F. Supp. 229 (S.D.N.Y. 1981) (upholding the right of employers to prohibit their employees from wearing braided hairstyles)); Angela P. Harris, Race and Essentialism in Feminist Legal Theory, 42 STAN. L. Rev. 581, 585 (1990) (criticizing feminist scholars Catharine MacKinnon and Robin West for advocating "gender essentialism-the notion that a unitary, 'essential' women's experience can be isolated and described independently of race, class, sexual orientation, and other realities of experience"); Cathy Scarborough, Note, Conceptualizing Black Women's Employment Experiences, 98 YALE L.J. 1457 (1989) (discussing the application of Title VII to African American women and arguing that courts should recognize their unique experiences in this context); Peggie R. Smith, Separate Identities: Black Women, Work, and Title VII, 14 HARv. WOMEN's L.J. 21 (1991) (advocating judicial recognition of "interactive discrimination" in the context of Title VII).

243. Crenshaw, Demarginalizing the Intersection of Race and Sex, supra note 3, at 148. 
DeGraffenreid embraces what Professor Crenshaw calls "a single-axis framework."244 That is, DeGraffenreid rejects the possibility that discrimination against African American women can be distinct, containing elements of both sex-based and race-based discrimination. Instead, DeGraffenreid substitutes an overly simplistic calculus: "but for" the plaintiff's race, she would have been treated differently, or "but for" her gender, she would have been treated differently. ${ }^{245}$ A single-axis framework denies African American women a separate and distinct legal identity by forcing them to present their claims in "mutually exclusive categories of experience and analysis."246 Thus, proceeding from the CRT empowerment concept of equality, ${ }^{247}$ Professor Crenshaw argues that to the extent that legal institutions ignore the doubly asymmetrical position of African American women in Anerican society, these institutions disempower an entire group of Americans.

Turning to reconstructive measures, Professor Crenshaw maintains that the African American women plaintiffs in DeGraffenreid should have been allowed to bring a Title VII claim based on both sex and race discrimination. ${ }^{248}$ Thus, she supports a Title VII cause of action for compound discrimination. ${ }^{249}$ But in nuaking her case, Professor Crenshaw, unlike the reformists, does not attempt to refute the traditionalists' "process concerns" about the creation of a compound discrimination cause of action. Professor Crenshaw's silence nray be attributable to the CRT approach to racial equality. CRT proceeds from the premise that fairness to outsider groups, such as African American women, should constitute the central concern of civil rights policy. Accordingly, Professor Crenshaw's implicit assumption might be that civil rights policy should subordinate evidentiary and admin-

244. Id. at 139.

245. Professor Crenshaw uses an inventive allegory to describe how a single-axis framework may subordinate black women:

Imagine a basement which contains all people who are disadvantaged on the basis of race, sex, class, sexual preference, age and/or physical ability. These people are stacked-feet standing on shoulders - with those on the bottom being disadvantaged by the full array of factors, up to the very top, where the heads of all those disadvantaged by a singular factor brush up against the ceiling. Their ceiling is actually the floor above which only those who are not disadvantaged in any way reside. In efforts to correct some aspects of domination, those above the ceiling admit from the basement only those who can say that "but for" the ceiling, they too would be in the upper room. A hatch is developed through which those placed immediately below can crawl. Yet this hatch is generally available only to those who-due to the singularity of their burden and their otherwise privileged position relative to those below-are in the position to crawl through. Those who are multiply-burdened are generally left below unless they can somehow pull themselves into the groups that are permitted to squeeze through the hatch.

Id. at 151-52.

246. Id. at 139.

247. See supra text aecompanying note 59. 49.

248. Crenshaw, Demarginalizing the Intersection of Race and Sex, supra note 3, at 142-43, 148 -

249. See id. at 149 (acknowledging that "sometimes, [African American women] experience discrimination as Black women-not the sum of race and sex discrimination, but as Black women."). 
istrative concerns to the goal of empowering African American women. If this is true, then Professor Crenshaw may not feel compelled, as do reformists, to balance the civil rights interests of African American women against those competing considerations.

However, race crits may not be of one mind on this issue. For example, one scholar who seems to subscribe to an empowerment concept of equality has suggested that the burden on employers that accompanies the recognition of compound claims could be weighed against the interests of African American women in being free from employment discrimination. ${ }^{250}$ This approach assumes that the concerns of employers and those of African American women deserve equal consideration, at least until the results of the balancing test are in.

Concerning intersectionality, then, we see stark microtheoretical contrasts between race crits and traditionalists. We speculate that traditionalists would view the DeGraffenreid approach as conceptually coherent and operationally sensible. Race crits, on the other hand, view the DeGraffenreid approach as conceptually incoherent and ineffective as a means to promote the interests of African American women. Microtheoretical differences between race crits and reformists are less striking. Both race crits and reformists offer similar deconstructive analyses and reconstructive prescriptions. Both use insights from the social sciences to draw a rich and complex picture of the employment experiences of African American women. And both criticize DeGraffenreid for ignoring the vital intersection of race and gender, thereby denying African American women complete protection under Title VII. While the reformists seem more concerned than the race crits with necessary sociolegal trade-offs, race crits may not be entirely unconcerned with such trade-offs. Finally, both race crits and reformists endorse the recognition of a compound discrimination cause of action as a reconstructive measure. Therefore, the CRT intersectionality analysis has not contributed a perspective on Title VII employment discrimination claims that differs substantially from that offered by the reformists.

\section{The Abolition of Title VII}

No self-respecting classical-liberal would ever suggest it, but CRT has gone so far as to advocate the abolition of Title VII. Traditionalists and reformists are in complete agreement that Title VII is an essential ingredient of a racially just society. They merely disagree about how Title VII is to be applied. But Professor Bell, the creator and leading proponent of CRT, has proposed that we jettison Title VII and allow employers to discriminate if they are willing to pay for the privilege of maximizing this particular utility.

250. Judy Scales-Trent, Black Women and the Constitution: Finding Our Place, Asserting Our Rights, 24 Harv. C.R.-C.L. L. Rev. 9, 38 n.142 (1989) (concluding that the rights of African American women would surely outweigh those of employers in such a balancing). 
Indeed, Professor Bell's proposal is not limited to Title VII; it applies to all civil rights law.

Because we do not want to risk unintentionally distorting Professor Bell's unusual proposal, "The Racial Preference Licensing Act," we shall present the proposal in his own words. We ask the reader's indulgence as we offer this extensive quotation from Professor Bell's scholarship:

The Racial Preference Licensing Act

Racial nepotism rather than racial animus is the major motivation for much of the discrimination blacks experience.

-Matthew S. Goldberg

It was enacted as the Racial Preference Licensing Act. At an elaborate, nationally televised signing ceremony, the Presidentelected as a "racial moderate"-assured the nation that the new statute represented a realistic advance in race relations. "It is," he insisted, "certainly not a return to the segregation policies granted constitutional protection under the stigma-inflicting 'separate but equal' standard of Plessy v. Ferguson established roughly a century ago.

"Far from being a retreat into our unhappy racial past," he explained, "the new law embodies a daring attempt to create a brighter racial future for all our citizens. Racial realism is the key to understanding this new law. It does not assume a nonexistent racial tolerance, but boldly proclaims its commitment to racial justice through the working of a marketplace that recognizes and seeks to balance the rights of our black citizens to fair treatment and the no less important right of some whites to an unfettered choice of customers, employees, and contractees."

Under the new act, all employers, proprietors of public facilities, and owners and managers of dwelling places, homes, and apartments could, on application to the federal government, obtain a license authorizing the holders, their managers, agents, and employees to exclude or separate persons on the basis of race and color. The license itself was expensive, though not prohibitively so. Once obtained, it required payment to a government commission of a tax of 3 percent of the income derived from whites employed, whites served, or products sold to whites during each quarter in which a policy of "racial preference" was in effect. Congress based its authority for the act on the commerce clause, the taxing power, and the general welfare clause of the Constitution.

License holders were required both to display their licenses prominently in a public place and to operate their businesses in accordance with the racially selective policies set out on their license. Specifically, discrimination had to be practiced in accordance with the license on a nonselective basis. Licenses were not 
available to those who, for example, might hire or rent to one token black and then discriminate against other applicants, using the license as a shield against discrimination suits. Persons of color wishing to charge discrimination against a facility not holding a license would carry the burden of proof, but such burden might be met with statistical and circumstantial as well as with direct evidence provided by white "testers." [Testing is an effective, but too little utilized, technique to ferret out bias in the sale and rental of housing or in employment practices. Generally, in testing, people who are alike in virtually every way except race or ethnicity are sent to apply for jobs, housing, or mortgages. The results are then analyzed for how differently whites are treated compared with black or Hispanic people. In 1982, the Supreme Court found that testers in a housing discrimination suit, and the housing association to which they were attached, had standing to sue in their own right as injured parties.] Under the act, successful complainants would be entitled to damages set at ten thousand dollars per instance of unlicensed discrimination, including attorneys' fees.

License fees and commissions paid by license holders would be placed in an "equality fund" used to underwrite black businesses, to offer no-interest mortgage loans for black home buyers, and to provide scholarships for black students seeking college and vocational education. To counter charges that black people, as under Plessy, would be both segregated and never gain any significant benefit from the equality fund, the act provided that five major civil rights organizations (each named in the statute) would submit the name of a representative who would serve on the commission for one, nonrenewable three-year term.

The President committed himself and his administration to the effective enforcement of the Racial Preference Licensing Act. "It is time," he declared, "to bring hard-headed realism rather than wellintentioned idealism to bear on our longstanding racial problems. Policies adopted because they seemed right have usually failed. Actions taken to promote justice for blacks have brought injustice to whites without appreciably improving the status or standards of living for blacks, particularly for those who most need the protection those actions were intended to provide.

"Within the memories of many of our citizens, this nation has both affirmed policies of racial segregation and advocated policies of racial integration. Neither approach has been either satisfactory or effective in furthering harmony and domestic tranquillity." Recalling the Civil Rights Act of 1964 and its 1991 amendments, the President pointed out that while the once-controversial publicaccommodation provisions in the original 1964 act received unam- 
mous judicial approval in the year of its adoption, even three decades later the act's protective function, particularly in the employment area, had been undermined by both unenthusiastic enforcement and judicial decisions construing its provisions ever more narrowly.

....

... "This bill I now sign into law is the result of long debate and good-faith compromise. It is, as its opponents charge and its proponents concede, a radical new approach to the nation's continuing tensions over racial status. It maximizes freedom of racial choice for all our citizens while guaranteeing that people of color will benefit either directly from equal access or indirectly from the fruits of the license taxes paid by those who choose policies of racial exclusion."251

Thus, Professor Bell's "Racial Preference Licensing Act" would permit businesses to discriminate at a price; they could only discriminate if they obtained a racial license, the proceeds of which would go into a public fund for racial minorities. Those who discriminated without a license would be liable for potentially massive monetary damages.

Several observations relative to the difference question ${ }^{252}$ can be made about the Racial Preference Licensing Act. First, the Act is the most ambitious reconstructive measure CRT has offered to date. It is utopian to say the least. Second, the Act is a reasonable response to the CRT deconstruction of FEO and the CRT concern for the on-going suffering of African Americans. ${ }^{253}$ Third, the Act is also a logical extension of both "racial realism," the belief that racial minorities should "abandon the ideal that racial equality can be obtained through law," ${ }^{254}$ and the CRT ideal of racial equality, a society that is racially asymmetrical and empowers minority perspectives. ${ }^{255}$

By proposing the Act, Professor Bell challenges us with the following argument. If racism is permanent, and if FEO and its regime of civil rights laws, designed by whites to promote their interests first and minority inter-

251. BeLL, supra note 46, at 47-52 (Editor's Note: the bracketed material in the quotation is taken from the author's annotation in the original) (footnotes omitted). In the text of the President's speech omitted from this passage, the President remarks that the Racial Preference Licensing Act is justified by the Supreme Court's opinion in Croson. He points out that the Court in Croson appeared to adopt Alexander Bickel's argument that the law fails when it tries to police morals. The Croson Court, according to the President, recharacterized Brown as "a call for a higher morality," id. at 51, and suggested that because Brown was a morals-policing attempt, it failed as an enforcement tool. The Racial Preference Licensing Act, however, does not seek to punish lawbreakers. Instead, the President contends, it respects citizens' right to determine for themselves what constitutes moral conduct and thus is supported by Croson, id. at 51-52.

252. See supra text accompanying note 3.

253. See supra Part II.A.

254. See supra note 56.

255. See supra Part II.B. 
ests second, cannot end racism, then why not try something new? Why not, Professor Bell seems to argue, permit whites to do what they are going to do anyway (discriminate) and, in the process, allow minorities a chance to improve their economic condition? Why not, in short, make the best of a bad situation?

Reformists might respond that the Act, in fact, would make a bad situation worse. They might analyze the Act as an attempt by Professor Bell to provide a reconstructive alternative to the reformists' affirmative action process, which Professor Bell has criticized as doing white liberals more good than it does minorities. ${ }^{256}$ Reformists might argue that the Act devalues middle class minorities more than affirmative action does. In the lawand-economics tradition, ${ }^{257}$ the Act places a monetary value on human dignity and racial suffering. The Act treats humanity like a commodity. It announces to the world that it is acceptable in America to treat minorities like dogs as long as they are fed on time. In short, reformists might argue that the externalities associated with the Act, particularly the digmity harms, far exceed those generated by the affirmative action process.

Nevertheless, the Act cannot be challenged for lack of originality. Both its deconstructive and reconstructive analyses are quite different from anything the traditionalists or reformists have said, let alone thought, about civil rights law. Having used the Racial Preference Licensing Act in a classroom setting, one of the authors of this Article knows firsthand that it pushes the inquiry in ways that classical-liberal deconstructive and reconstructive analyses do not. If Judge Posner has doubts about the value of CRT, ${ }^{258}$ he might want to read the Racial Preference Licensing Act.

\section{CONCLUSION}

Our discussion has considered both macro- and microtheoretical differences between CRT and classical-liberal civil rights scholarship. At the macrotheoretical level, we have seen that race crits regard formal equal opportunity (FEO), the nation's fundamental civil rights policy since Brown, as conceptually flawed since it embraces a symmetrical vision of racial equality. Classical-liberalism, on the other hand, maintains that FEO is conceptually sound and that the races should be treated symmetrically. However, one group of classical-liberals, the reformists, concedes that current applications of FEO are often fiawed because they are insufficiently attentive to the life experiences of racial minorities.

Whether these disparate macrotheoretical perspectives actually yield different results when applied to specific microtheoretical legal doctrines is, perhaps, the more important question. However, as we have seen, this

256. See supra text accompanying notes 144-47.

257. See supra note 39. The Act focuses more on minorities and has a broader scope than the longstanding law-and-economics proposal to abolish Title VII.

258. See supra note 8 and accompanying text. 
question can be answered categorically only if it is grossly oversimplified. In the Title VII context, while it is accurate to say that the race crits' discussion of accent discrimination law and their proposal for the Racial Preference Licensing Act differ unmistakably from what we would expect from classical-liberals (traditionalists and reformists), the same is not true with respect to their analyses of intersectionality.

Furthermore, CRT clearly has more to contribute in some doctrinal areas than in others. While CRT's deconstruction and reconstruction of equal protection law's standards of liability and judicial review are substantially different from the traditionalists' and reformists' treatments, CRT's reconstructive proposal for the standard of liability, a "culturally informed" intent test, is arguably less socially transformative than the reformists' proposed "effects test."

How one assesses the overall value of CRT's contribution is a more difficult question. Perhaps CRT scholarship has already articulated the standard by which it should be judged. A leading race crit, Professor Charles Lawrence has suggested that CRT scholarship "must strive to be both pragmatic and utopian. Our work must respond to the immediate needs of the oppressed and subordinated."259 Applying this standard, one can argue that CRT's value derives from the utopian nature of its "empowerment" conception of racial equality. Likewise, the race crits' deconstruction of accent discrimination law and the intent test may be deemed valuable because of its idealism and sensitivity to minority perspectives. Professor Bell's Racial Preference Licensing Act certainly fits this bill. However, whether CRT's reconstructive proposals also "respond to the immediate needs of the oppressed and subordinated" is a more difficult question. Does Professor Lawrence's modified "culturally informed" intent test respond more effectively to those needs than the reformists' effects test? How "pragmatic" are Professors Lawrence, Matsuda, and Bell's reconstructive proposals if each stands little chance of actually being adopted by the courts or Congress? These issues make it somewhat unclear whether CRT satisfies its own criteria for admission into the canon of legal knowledge.

Perhaps, however, it may be better to judge CRT scholarship according to externally-generated, more "traditional" standards. Specifically, it may be better to treat any scholarship, whether MLS, CRT or classicalliberal, as valuable if it creates new knowledge or brings fresh insights to the table. By this measure, CRT has clearly produced valuable scholarship. More than any other form of legal scholarship, CRT, at both the macro-and

259. Charles R. Lawrence, III, The Word and the River: Pedagogy as Scholarship as Struggle, 65 S. CAL. L. Rev. 2231, 2239 (1992); see also Richard Delgado, On Telling Stories in School: A Reply to Farber and Sherry, 46 VAND. L. REv. 665, 673-74 (1993) ("Outsider scholarship is often aimed not at understanding the law, but at changing it."). For criticism of this view, see Daniel A. Farber \& Suzanna Sherry, The 200,000 Cards of Dimitri Yurasov: Further Reflections on Scholarship and Truth, 46 STAN. L. REv. 647 (1994) (suggesting that the goal of scholarship should be to discover and communicate truth, not to advance the interests of a particular community). 
microtheoretical levels, conveys the minority perspective. It speaks with a minority "voice" and is much more in touch with minority sensibilities than classical-liberalism, even if its proposed solutions may not always 'be the most pragmatic. Moreover, perhaps as a result of its minority-sensitive approach, CRT's microtheoretical analyses are often more contextualized and sophisticated than those of classical-hiberal scholarship; at least this seems to be the case when CRT has a fresh perspective on an issue. ${ }^{260}$

Finally, although we have argued that CRT satisfies the new-knowledge/fresh-insight standard, qualifying CRT for inclusion in the modern canon of legal knowledge, CRT is more than just a valuable academic exercise. Because it brings an "outsider" perspective to the discussion, CRT has substantial transformative potential. As Alice Walker reminds us, "[e]xperience adds to experience."261 CRT scholarship demands recogmtion that our multicultural society cannot hope to achieve racial justice until we pay more attention to the unique experiences of racial minorities.

260. Compare CRT's analyses of the intent test, see supra Part III.A.3., and accent discrimination, see supra Part IV.A.3., with CRT's less innovative analysis of intersectionality, see supra Part IV.B.3.

261. Alice Walker, Brothers and Sisters, in TEN ON TEN: MAJOR Essayists ON RECURRING Themes 259, 273 (Robert Atwan ed., 1992). 


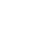

